ISSN 1996-1073

www.mdpi.org/energies

Review

\title{
Biofuel Impacts on World Food Supply: Use of Fossil Fuel, Land and Water Resources
}

\author{
David Pimentel *, Alison Marklein, Megan A. Toth, Marissa Karpoff, Gillian S. Paul, \\ Robert McCormack, Joanna Kyriazis and Tim Krueger
}

5126 Comstock Hall, Cornell University, Ithaca, NY 14853, USA

* Author to whom correspondence should be addressed; E-mail: Dp18@ cornell.edu

Received: 29 July 2008 / Accepted: 11 September 2008 / Published: 16 September 2008

\begin{abstract}
The rapidly growing world population and rising consumption of biofuels are increasing demand for both food and biofuels. This exaggerates both food and fuel shortages. Using food crops such as corn grain to produce ethanol raises major nutritional and ethical concerns. Nearly $60 \%$ of humans in the world are currently malnourished, so the need for grains and other basic foods is critical. Growing crops for fuel squanders land, water and energy resources vital for the production of food for human consumption. Using corn for ethanol increases the price of U.S. beef, chicken, pork, eggs, breads, cereals, and milk more than $10 \%$ to $30 \%$.
\end{abstract}

Keywords: agriculture, biofuels, energy, food security, fossil fuels, natural resources, renewable energy.

\section{Introduction}

With shortages of fossil energy, especially oil and natural gas, and heavy biomass energy consumption occurring in both developed and developing countries, a major focus has developed worldwide on biofuel production [1-3]. Emphasis on biofuels has developed globally, including those made from crops such as corn, sugarcane, and soybean, considered by some researchers as renewable energy sources. Wood and crop residues also are being used as fuel [4]. Though it may seem beneficial to use renewable plant materials for biofuel, the use of crop residues and other biomass for biofuels raises concerns about major environmental impacts [5]. 
Conflicts exist today in the use of land, water, energy, and other environmental resources required by both food and biofuel production. Although much of the land worldwide is occupied by grain and other crops, malnutrition is still the leading cause of death in the world today [6]. The World Health Organization [7] reports that more than 3.7 billion people (56\% of the global population) are currently malnourished and that number is steadily increasing. Grains make up more than $80 \%$ of the world food supply, and unfortunately the Food and Agricultural Organization of the United Nations reports that per capita grain production has been declining for the past 23 years [8,9]. This suggests that the nutritional needs of the human population will require an increasing amount of agricultural resources as food.

Food and biofuels are dependent on the same resources for production: land, water, and energy. In the U.S., about $19 \%$ of all fossil energy is utilized in the food system, including about $7 \%$ for agricultural production, $7 \%$ for processing and packaging foods, and about 5\% for distribution and preparation of food [10]. In developing countries, about 50\% of wood energy is used primarily for cooking in the food system [11]. Worldwide, the process of turning natural resources into food requires large amounts of energy, land, and water resources. The objective of this article is to analyze: (1) the reliance of both food and biofuel for the same land, water, and fossil energy resources in food versus biofuel production and (2) the characteristics of the environmental impacts caused by food and biofuel production.

\section{Food supply and malnourishment in the world}

Serious problems face the world food supply today. The human population faces serious food shortages and malnutrition [7]. Considering this crisis, the Food and Agricultural Organization (FAO) of the United Nations confirms that worldwide food available per capita has been declining continuously based on availability of cereal grains during the past 23 years [8], which make up alarmingly about $80 \%$ of the world's food supply [9]. Although grain yields per hectare in both developed and developing countries are still gradually increasing, the rate of increase is slowing, while the world population and its food needs are rising rapidly [8,12]. For example, from 1950 to 1980, U.S. grain yields increased at about $3 \%$ per year, but since 1980, the annual rate of increase for corn and other other grains is only approximately $1 \%$ [13]. Therefore, the rate of increase in grain production is not keeping up with the rapid rate of world population growth of $1.2 \%$ [12].

In 2005, the World Health Organization reported the largest number and proportion of malnourished people, 3.7 billion [7]. This is the largest number and proportion of malnourished people ever reported. Their assessment of malnutrition includes deficiencies in calories, protein, iron, iodine, and vitamins A, B, C, and D [14,15]. Others, like FAO [16], report that 850 million people are malnourished (based only on protein/calorie malnourishment). However, this estimate is low because it does not account for the strenuous work and micronutrient deficiencies that affect billions of people worldwide [17]. Malnutrition is especially difficult for children because of their rapid growth and activity. Malnutrition is the underlying cause of more than half of the deaths of children under 5 years old worldwide [18]. Furthermore, the UN reports over 9 million people die from starvation each year [19]. Food shortages are also related to such problems as distribution, wars, droughts, and climate change. 
In order to solve the problem of malnutrition in the world, the U.S. must address over-consumption of food, fuel, and other resources. The average American consumes more than 1,000 kg (2,200 lbs) of food per year [20]. This is the equivalent of an average of 3,800 kcal per day, whereas the average male only requires 2,400 kcal and female 2,000 kcal per day [20]. The U.S. over-consumption is compounded by the massive use of fats and sweets in the diet [21].

Growing crops for biofuel will only exacerbate the problem of resource allocation, for biofuel production depletes land, water, and energy resources for human food production.

\section{World cropland resources}

More than $99.7 \%$ of human food comes from the terrestrial environment, while less than $0.3 \%$ comes from the oceans and other aquatic ecosystems [22]. Most of the suitable land for biomass production is already in production. Worldwide, of the total 13 billion hectares of land area on earth the percentages in use are: cropland, $11 \%$; pasture land, 27\%; forest land, 32\%; urban, 9\%; and other $21 \%$. The remaining land $(21 \%)$ is unsuitable for crops, pasture, and/or forests because the soil is too infertile or shallow to support plant growth, or the climate and region are too cold, dry, steep, stony, or wet [23]. Thus, most suitable land for production is already is in use.

In 1999 the United Nations reported that only 0.22 ha of cropland per capita was available worldwide [24,25]; however, 0.5 ha is considered essential. In 1960, when the world population numbered only 3 billion, approximately 0.5 ha per capita was available for the production of a diverse, nutritious diet of plant and animal products [26].

As the human population continues to increase, there has been an expansion of diverse human activities, which has reduced available cropland and pasture land. For example, vital cropland and pasture land has been covered by transportation systems and urbanization. In the U.S., each person in the population uses 0.4 ha ( 1 acre) of land for urbanization and highways [27]. China's recent explosion in development provides an example of rapid declines in the availability of per capita cropland [28]. The current amount of available cropland in China is only 0.08 ha per capita (Table 1). This relatively small amount of cropland provides the people in China with a predominantly vegetarian diet, which requires less energy, land, and biomass than a typical American diet.

Table 1. Resources used and/or available per capita per year in the U.S., China, and the world to supply basic human needs [23].

$\begin{array}{llll}\text { Resources } & \text { U.S. } & \text { China } & \text { World } \\ \text { Land } & & & \\ \text { Cropland (ha) } & 0.48 & 0.08 & 0.22 \\ \text { Pasture (ha) } & 0.79 & 0.33 & 0.52 \\ \text { Forest (ha) } & 0.79 & 0.11 & 0.59 \\ \text { Total (ha) } & 2.78 & 0.46 & 1.97 \\ \text { Water (liters x 106) } & 2.0 & 0.46 & 0.60 \\ \text { Fossil fuel (BP, 2005) } & & & \\ \text { Oil equivalents (liters) } 9,500 & & 1,400 & 2,100\end{array}$


As a result of world population growth, the average available cropland per capita worldwide has now diminished to less than 0.22 ha (a total of 1.5 billion ha of cropland [25]. This is about half the amount currently available in the U.S.; the average cropland per capita in the U.S. has also declined to $0.48 \mathrm{ha}$, or less than the critical land area essential for diverse food production (Table 1).

The availability of cropland influences the kinds and types of foods produced. For example, at present, a total of $1,400 \mathrm{~kg} / \mathrm{yr}$ per capita of agricultural product is produced to feed each American, while the Chinese food supply averages only $800 \mathrm{~kg} / \mathrm{yr}$ per capita [28]. By all available measurements, the Chinese have reached or exceeded the limits of their agricultural system. Furthermore, the reliance of the Chinese on large inputs of fossil-fuel based fertilizers to compensate for shortages of arable land and severely eroded soils, and a limited fresh water supply, suggest severe problems looming in the near future [28]. Today, China imports large amounts of grain from the United States and other nations and is expected to further increase grain imports in the near future, because of land and water shortages.

\section{World water resources}

Water is a vital resource for crop production and human survival [30]. The production of $9 \mathrm{t} / \mathrm{ha}$ of corn requires about 7 million liters of water (about 700,000 gallons of water per acre) [31]. However, world irrigation has declined about 10\% during the past 10 years based on World Bank lending [32]. This is of critical importance because $17 \%$ of the crops that are irrigated provide $40 \%$ of the world food supply [22]. Thus, the world's capacity for food production is becoming limited by declining water resources.

\section{Energy resources}

Humans have relied on various sources of power for centuries, but solar energy is the ultimate source of global production. Biologically captured solar energy is vital to all natural ecosystems and to maintaining the diversity of all life systems. Other energy sources have ranged from human power, animal, wind, tidal, and water energy to wood, coal, gas, oil, and nuclear sources for fuel and power. Since about the year 1700, abundant fossil fuel energy supplies have made it possible to augment agricultural production to feed an increasing number of humans [9]. For example, energy availability has made possible the purification and transport of water, reduced human diseases, and a generally enhanced quality of human life.

Since the industrial revolution of the 1850's, the total rate of energy use from all sources has been growing even faster than world population growth. From 1970 to 1995, energy use increased at a rate of $2.5 \%$ per year (doubling every 30 years) compared with the worldwide population growth of $1.7 \%$ per year (doubling every 40 to 60 years) [9]. The use and availability of energy resources will start to decline slowly and continuously until little or no oil and gas resources remain [33-35].

About $50 \%$ of all the solar energy captured by worldwide photosynthesis is used by humans for food, forest products, and other systems. However, it is still inadequate to meet all current human needs - namely, food needs [36]. To make up for this shortfall, about 473 quads ( 1 quad $=1 \times 10^{15}$ BTU) of fossil energy, mainly oil, gas, coal, and a small amount of nuclear, are utilized worldwide 
each year (Table 2). Of the 473 quads, about 100 quads (or about 22\%) of the world's total energy are utilized in the United States [27].

Table 2. Fossil and solar energy use in the U.S. and world (quads $=10^{15}$ BTU) [27].

\begin{tabular}{lll} 
Fuel & U.S. & World \\
\hline Petroleum & 40.1 & 168 \\
Natural Gas & 23.0 & 103 \\
Coal & 22.3 & 115 \\
Nuclear & 8.2 & 28 \\
Biomass & 3.0 & 30 \\
Hydroelectric power & 3.4 & 27 \\
Geothermal and windpower & 0.4 & 0.8 \\
Biofuels & 0.5 & 0.9 \\
Total & 100.9 & 472.7
\end{tabular}

\subsection{Solar Energy Captured by Green Plants}

A large amount of vegetation biomass is required to supply the growing human population with usable biomass energy. Some estimate that approximately $0.5 \%$ of the solar energy reaching the earth is captured by green plants [37]. In the U.S., Pimentel and Patzek (2006) [38] estimate that 0.1\% of total solar energy is captured by green plants (Table 3). The U.S. has a total land area of 917 million hectares and a current population of 302 million [12]. The U.S. population adds 3.3 million more humans per year with a rate of increase at $1.1 \%$, which is more than double the rate of increase in China at $0.5 \%$ [12]. This growing population will result in more land used for urbanization, highways, and food production, all of which will further stress U.S. natural resources.

Table 3. Total amount of above ground biomass except for some crops that include underground biomass and solar energy captured each year in the United States. An estimated $32 \times 10^{15}$ BTU of sunlight captured in the U.S. per year suggests that the green plants in the U.S. are collecting $0.1 \%$ of the solar energy [39-42].

$\begin{array}{lrr}\text { Crops } & 901 \times 10^{6} \text { tons } & 14.4 \times 10^{15} \mathrm{BTU} \\ \text { Pasture } & 600 \times 10^{6} \text { tons } & 9.6 \times 10^{15} \mathrm{BTU} \\ \text { Forest } & 527 \times 10^{6} \text { tons } & 8.4 \times 10^{15} \mathrm{BTU} \\ \text { Total } & 2,028 \times 10^{6} \text { tons } & 32.4 \times 10^{15} \mathrm{BTU}\end{array}$

Nearly one half (45\%) of the land area in the United States is already used for crops and pastures [20]. The forest land area covers $30 \%$. Urban areas and highways cover approximately $3 \%$, with miscellaneous areas covering about 23\% [20]. 


\subsection{U.S. Energy Use}

Each year, the U.S. population uses 3 times as much fossil energy as the total solar energy captured by harvested U.S. crops, forest products, and other vegetation (Tables 1-3). Industry, transportation, home heating and cooling, and food production account for most of the fossil energy consumed in the United States [27]. Per capita use of fossil energy in the United States per year amounts to about 9,500 liters of oil equivalents -- more than 7-times the per capita use in China (Table 1). In China, most fossil energy is used by industry, although a substantial amount, approximately $25 \%$, is now used for agriculture and in the food production system [28].

Taken together, developed nations annually consume about $70 \%$ of the fossil energy worldwide, while the developing nations, which represent about $75 \%$ of the world population, use only $30 \%$ of world fossil energy [43]. The United States, with only $4.5 \%$ of the world's population, is a major consumer of fossil energy and annually consumes about $22 \%$ of the world's fossil energy output (Table 2).

Some developing nations that are experiencing especially high rates of population growth are increasing fossil fuel use to help augment their agricultural production of food and fiber. For example, since 1955 in China, there has been a 100-fold increase in fossil energy use in agriculture for fertilizers, pesticides, and irrigation [28]. However, as fossil energy resources decline, the use of fossil energy will become limited for food production, causing even more severe food shortages for the rapidly growing world population.

Worldwide fertilizer use per capita has declined by more than $22 \%$ since 1989 , especially in the developing countries, due to fossil fuel shortages and high prices for fertilizers [44]. During the past 5 years, nitrogen fertilizer costs have more than doubled in the U.S. [45]. In addition, the overall projections of available fossil energy resources for manufacturing fertilizers and all other purposes are discouraging as the reserves of these finite fossil fuels rapidly diminish.

\subsection{Fossil Fuel Supplies}

World oil production has peaked and projections are that by 2040 oil will decline to about $62 \%$ below peak (W. Youngquist, petroleum geologist, Eugene, OR, 30 April, 2008). The world supply of oil is projected to last approximately 40-60 years, if use continues at current production rates [29]. Natural gas is considered adequate for about 30 years and coal for less than 100 years [29,46]. In the U.S., natural gas is already in short supply; it is projected that the U.S. will deplete its natural gas resources in about 20 years [33].

Initial drilling for oil and gas provided optimistic estimates of fossil fuel resources in the U.S. [46]. However, both the U.S. oil production rate and existing reserves have been declining for more than 30 years [27, 47]. To date, approximately $90 \%$ of U.S. oil resources have already been exploited (W. Youngquist, personal communication, petroleum geologist, Eugene, Oregon, 2002) [48]. At present, the United States is importing more than $65 \%$ of its oil [27], which puts the U.S. economy at risk due to fluctuating oil prices and difficult international political situations. 


\section{Biomass Resources}

Worldwide, most biomass is burned for cooking and heating; however, it can also be converted into electricity. Assuming an optimal yield of 3 dry metric tons ( $\mathrm{t} / \mathrm{ha}$ ) per year of woody biomass can be harvested sustainably, this would provide a gross energy yield of 13.5 million $\mathrm{kcal} / \mathrm{ha}[49,50]$. Harvesting this wood biomass requires an energy expenditure of approximately 30 liters of diesel fuel per ha, not including the embodied energy for cutting and collecting wood for transport to an electric power plant. Thus, the energy input per output ratio for such a system is calculated to be 1:25 [51].

Fuelwood provides an important source of biomass energy used for industry and homes in the United States, accounting for $3 \%$ of the total energy use in the U.S. [27]. About $60 \%$ of this biomass is wood-waste fuel from paper producing plants, lumber mills, and furniture producing plants [27]. Approximately $30 \%$ of the wood is utilized in homes and power plants as fuel [52].

The cost of producing $1 \mathrm{kWh}$ of electricity from woody biomass in the U.S. is about $\$ 0.06$, which is competitive with other electricity production systems that average $\$ 0.08$ in the U.S. [27,53]. Approximately $3 \mathrm{kWh}$ of thermal energy is expended to produce $1 \mathrm{kWh}$ of electricity, an energy input/output ratio of 1:3. Per capita consumption of woody biomass for heat in the U.S. amounts to 625 kilograms (kg) per year. The diverse biomass resources (wood, crop residues, and dung) used in developing nations averages about $630 \mathrm{~kg}$ per capita per year [54]. Developing countries use only about 500 liters of oil equivalents of fossil energy per capita compared with nearly 9,500 liters of oil equivalents of fossil energy used per capita in the U.S. (Table 1) [55].

Woody biomass has the capacity to supply the U.S. with about 5 quads ( $1.5 \times 10^{12} \mathrm{kWh}$ thermal) of its total gross energy supply by the year 2050, provided that the amount of forest land stays constant [56]. A city of 100,000 people using the biomass from a sustainable forest ( $3 \mathrm{t} / \mathrm{ha}$ per year) for electricity requires approximately 200,000 ha of forest area, based on an average electrical demand of slightly more than 1 billion kWh (electrical energy [e]) (860 kcal = 1 kWh) [56].

Environmental impacts of burning biomass are less harmful than those associated with coal, but more harmful than those associated with natural gas [36]. Biomass combustion releases more than 200 different chemical pollutants, including 14 carcinogens and 4 co-carcinogens, into the atmosphere [57]. As a result of this, but especially in developing nations where people cook with fuelwood over open fires, approximately 4 billion people suffer from continuous exposure to smoke [58]. In the U.S., wood smoke kills 30,000 people each year [59], although many of the pollutants from electric plants that use wood and other biomass can be mitigated. These controls include the same scrubbers that are frequently installed on coal-fired plants.

\subsection{Regional Benefits of Thermal Energy from Biofuels}

Direct combustion is the most efficient use of wood biomass. Space heating in the U.S. is a major component of both residential and commercial buildings. In total, the amount of energy used in these sectors totals about 16 quads per year [27]. Currently, only an estimated 1\% of U.S. homes are heated with wood biomass [60]. If $10 \%$ of the forest biomass in the Midwest, Northeast, and Southeast (that totals an estimated 100 million hectares) plus $10 \%$ of the grass biomass (that totals an estimated 26 million hectares) were harvested, this thermal energy would be a major asset to the nation [20]. The estimated sustainable forest and grass biomass produced per hectare per year is about $2 \mathrm{t} / \mathrm{ha} / \mathrm{yr}$ without 
any fertilizer or other inputs (Table 3) [42]. Assuming half of the energy harvested from these biomass areas is utilized for harvesting, transport, and processing, about 0.032 quads of thermal energy can be utilized from the forest land, and 0.016 quads of thermal energy can be utilized from the grassland area. This would total about $0.05 \%$ of total energy use in the U.S. (Table 2). Areas in the Northeast that use wood for space heating, have become reforested as many farmlands were abandoned, and are now major sources of wood biomass.

Increasing the use of wood biomass for heating homes will increase the number of illnesses, like asthma and death [57]. Some communities, like Aspen, Colorado, already have banned the use of wood fuels for heating, due to many adverse health effects [61].

\section{World Forest Biomass}

The total sustainable world biomass energy potential has been estimated to be about 92 quads ( $10^{15}$ BTU) per year [62], which represents $19 \%$ of total global energy use (Table 2). The total forest biomass produced worldwide is 38 quads per year [62], which represents $8 \%$ of total energy use (Table 2). In the U.S., only $1 \%$ to $2 \%$ home heating is achieved with wood [63]. Of the 106 million U.S. homes that heat their homes, 2.0 million use wood as the main heating fuel (3\%) [64].

Global forest area removed each year totals 15 million ha [65]. Global forest biomass harvested is just over 1,431 billion $\mathrm{kg}$ per year, of which $60 \%$ is industrial roundwood and $40 \%$ is fuelwood [66]. About $90 \%$ of the fuelwood is utilized in developing countries [62]. A significant portion (26\%) of all forest wood is converted into charcoal [67]. The production of charcoal causes a $30 \%$ to $50 \%$ loss of energy [68], and produces large quantities of smoke. The resulting charcoal is cleaner burning and causes less smoke than burning wood fuel directly in the home [67]. Charcoal is dirty to handle but light in weight.

In developing countries, about $2 \mathrm{kcal}$ of wood are utilized in cooking $1 \mathrm{kcal}$ of food [69]. Thus, more biomass and more land and water are needed to produce the biofuel for cooking than the resources needed to produce the food.

In the U.S., about $30 \%$ of the land area is forested and produces 239 billion $\mathrm{kg}$ of wood biomass per year [20]. The total forest products harvested per year per person in the U.S. is $914 \mathrm{~kg}$, but only 71 $\mathrm{kg}$ is used for firewood [70]. The rest is used for the production of lumber and pulp for paper production.

The average yield of forest biomass in U.S. timberland is 1.93 dry metric tons/ha/yr [42]. Under sustainable, moist, forest conditions in both temperate and tropical ecosystems, approximately 3 dry metric tons (t/ha) per year of woody biomass can be harvested sustainably [50,71-73].

\section{Cropland and Pasture Biomass}

Of the total world land area in cropland, pasture, and forest, about $38 \%$ is cropland and pasture and about 30\% is forests [23]. Devoting a portion of this cropland and forest land to biofuels will stress both managed ecosystems and will not be sufficient to solve the fuel problem [1]. 


\subsection{Corn Ethanol and Energy Inputs}

In the United States, ethanol constitutes $99 \%$ of all biofuels [74]. The average, energy and monetary costs, for a large modern ethanol plant are enormous, about $\$ 65$ million. For capital expenditures, new plant construction costs from $\$ 1.05$ to $\$ 3.00$ per gallon of ethanol [75]. Fermenting and distilling corn ethanol requires large amounts of water. The corn is finely ground and approximately 15 liters of water are added per $2.69 \mathrm{~kg}$ of ground corn. After fermentation, to obtain a liter of $95 \%$ pure ethanol from the $10 \%$ ethanol and $90 \%$ water mixture, 1 liter of ethanol must be extracted from the approximately 10 liters of the ethanol/water mixture. To be mixed with gasoline, the $95 \%$ ethanol must be further processed and more water must be removed, requiring additional fossil energy inputs to achieve $99.5 \%$ pure ethanol (Tables 4 and 5). Thus, a total of about 12 liters of wastewater must be removed per liter of ethanol produced, and this relatively large amount of sewage effluent has to be disposed of at an energy, economic, and environmental cost.

Table 4. Energy inputs and costs of corn production per hectare in the United States.

\begin{tabular}{llll} 
Inputs & Quantity & kcal x 1000 & Costs \$ \\
\hline Labor & $11.4 \mathrm{hrs}^{\mathrm{a}}$ & $426^{\mathrm{b}}$ & $300.00^{\mathrm{c}}$ \\
Machinery & $55 \mathrm{~kg}^{\mathrm{d}}$ & $1,018^{\mathrm{e}}$ & $310.00^{\mathrm{f}}$ \\
Diesel & $88 \mathrm{~L}^{\mathrm{g}}$ & $1,003^{\mathrm{h}}$ & 500.00 \\
Nitrogen & $155 \mathrm{~kg}^{\mathrm{k}}$ & $2,480^{1}$ & $255.00^{\mathrm{m}}$ \\
Phosphorus & $79 \mathrm{~kg}^{\mathrm{n}}$ & $328^{\mathrm{o}}$ & $150.00^{\mathrm{p}}$ \\
Potassium & $84 \mathrm{~kg}^{\mathrm{q}}$ & $274^{\mathrm{r}}$ & $78.00^{\mathrm{s}}$ \\
Lime & $1,120 \mathrm{~kg}^{\mathrm{t}}$ & $315^{\mathrm{u}}$ & 60.00 \\
Seeds & $21 \mathrm{~kg}^{\mathrm{v}}$ & $520^{\mathrm{w}}$ & $230.00^{\mathrm{x}}$ \\
Irrigation & $8.1 \mathrm{~cm}^{\mathrm{y}}$ & $320^{\mathrm{z}}$ & $350.00^{\mathrm{aa}}$ \\
Herbicides & $6.2 \mathrm{~kg}^{\mathrm{bb}}$ & $620^{\mathrm{ee}}$ & 372.00 \\
Insecticides & $2.8 \mathrm{~kg}^{\mathrm{cc}}$ & $280^{\mathrm{ee}}$ & 180.00 \\
Electricity & $13.2 \mathrm{Wh}^{\mathrm{dd}}$ & $34^{\mathrm{ff}}$ & 27.00 \\
Transport & $204 \mathrm{~kg}^{\mathrm{gg}}$ & $169^{\mathrm{hh}}$ & 180.00 \\
TOTAL & & 8,228 & $\$ 2,992.00$ \\
Corn yield & $9,400 \mathrm{~kg} / \mathrm{ha}$ & $33,840 \mathrm{kcal}$ input:output $1: 4.11$ \\
\hline
\end{tabular}
a) NASS, 2003 [76].
b) It is assumed that a person works 2,000 hrs per year and utilizes an average of 8,000 liters of oil equivalents per year.
c) It is assumed that labor is paid $\$ 26.32$ an hour.
d) Pimentel and Pimentel, 2008 [4].
e) Prorated per hectare and 10 year life of the machinery. Tractors weigh from 6 to 7 tons and harvesters 8 to 10 tons, plus plows, sprayers, and other equipment.
f) Estimated.
g) Estimated.
h) Input 11, $400 \mathrm{kcal}$ per liter.
i) Estimated
j) Input 10,125 kcal per liter. 
k) NASS, 2003 [76].

1) Patzek, 2004 [77].

m) Cost $\$ 1.65$ per $\mathrm{kg}$.

n) NASS, 2003 [76].

o) Input 4,154 kcal per kg.

p) Cost $\$ 1.90$ per kg.

q) NASS, 2003 [76].

r) Input $3,260 \mathrm{kcal}$ per $\mathrm{kg}$.

s) Cost $\$ 0.93$ per kg.

t) Brees, 2004 [78]

u) Input $281 \mathrm{kcal}$ per $\mathrm{kg}$.

v) Pimentel and Pimentel, 2008 [4].

w) Pimentel and Pimentel, 2008 [4].

x) USDA, 1997 [79].

y) USDA, 1997 [80].

z) Batty and Keller, 1980 [81].

aa) Irrigation for $100 \mathrm{~cm}$ of water per hectare costs $\$ 1,000$ (Larsen et al., 2002) [82].

bb) Larson and Cardwell, 1999 [83].

cc) USDA, 2002 [84].

dd) USDA, 1991 [85].

ee) Input 100,000 kcal per $\mathrm{kg}$ of herbicide and insecticide.

ff) Input $860 \mathrm{kcal}$ per $\mathrm{kWh}$ and requires $3 \mathrm{kWh}$ thermal energy to produce $1 \mathrm{kWh}$ electricity.

gg) Goods transported include machinery, fuels, and seeds that were shipped an estimated 1,000 $\mathrm{km}$.

hh) Input $0.83 \mathrm{kcal}$ per $\mathrm{kg}$ per $\mathrm{km}$ transported.

ii) Average. [20,47].

Table 5. Inputs per 1000 liters of $99.5 \%$ ethanol produced from corn. ${ }^{\text {a }}$

\begin{tabular}{llll} 
Inputs & Quantity & Kcal x 1000 & Dollar \$ \\
\hline Corn grain & $2,690 \mathrm{~kg}^{\mathrm{b}}$ & $2,355^{\mathrm{b}}$ & 856.22 \\
Corn transport & $2,690 \mathrm{~kg}^{\mathrm{b}}$ & $322^{\mathrm{c}}$ & $21.40^{\mathrm{d}}$ \\
Water & $15,000 \mathrm{~L}^{\mathrm{e}}$ & $90 \mathrm{f}$ & $21.16^{\mathrm{g}}$ \\
Stainless steel & $3 \mathrm{~kg}^{\mathrm{i}}$ & $165^{\mathrm{p}}$ & $10.60^{\mathrm{d}}$ \\
Steel & $4 \mathrm{~kg}^{\mathrm{i}}$ & $92^{\mathrm{p}}$ & $10.60^{\mathrm{d}}$ \\
Cement & $8 \mathrm{~kg}^{\mathrm{i}}$ & $384^{\mathrm{p}}$ & $10.60^{\mathrm{d}}$ \\
Steam & $2,646,000 \mathrm{kcal}^{\mathrm{j}}$ & $2,646^{\mathrm{j}}$ & $21.16^{\mathrm{k}}$ \\
Electricity & $392 \mathrm{kWh}^{\mathrm{j}}$ & $1,011^{\mathrm{j}}$ & $27.44^{\mathrm{l}}$ \\
95\% ethanol to $99.5 \%$ & $9 \mathrm{kcal}^{\mathrm{m}}$ & $9^{\mathrm{m}}$ & 40.00 \\
Sewage effluent & $20 \mathrm{~kg} \mathrm{BOD}^{\mathrm{n}}$ & $69^{\mathrm{h}}$ & 6.00 \\
Distribution & $331 \mathrm{kcal} / \mathrm{L}^{\mathrm{q}}$ & 331 & $20.00^{\mathrm{q}}$ \\
TOTAL & & 7,474 & $\$ 1,045.18$ \\
\hline
\end{tabular}

a) Output: 1 liter of ethanol $=5,130 \mathrm{kcal}$ (Low heating value). The mean yield of 2.5 gal pure EtOH per bushel has been obtained from the industry-reported ethanol sales minus ethanol imports from Brazil, both multiplied by 0.95 to account for $5 \%$ by volume of the \#14 gasoline 
denaturant, and the result was divided by the industry-reported bushels of corn inputs to ethanol plants [86].

b) Data from table 4 .

c) Calculated for $144 \mathrm{~km}$ roundtrip.

d) Pimentel, 2003 [87].

e) 15 liters of water mixed with each $\mathrm{kg}$ of grain.

f) Pimentel et al., 2004 [31].

g) Pimentel et al., 2004 [31].

h) $4 \mathrm{kWh}$ of energy required to process $1 \mathrm{~kg}$ of BOD [88].

i) Estimated from the industry reported costs of $\$ 85$ millions per 65 million gallons/yr dry grain plant amortized over 30 years. The total amortized cost is $\$ 43.6 / 1000 \mathrm{~L} \mathrm{EtOH}$, of which an estimated $\$ 32$ go to steel and cement.

j) Illinois Corn, 2004 [89]. The current estimate is below the average of 40,000 Btu/gal of denatured ethanol paid to the Public Utilities Commission in South Dakota by ethanol plants in 2005.

k) Calculated based on coal fuel. Below the $1.95 \mathrm{kWh} /$ gal of denatured EtOH in South Dakota, see $\mathrm{j}$ ).

1) $\$ .07$ per $\mathrm{kWh}[47]$.

m) $95 \%$ ethanol converted to $99.5 \%$ ethanol for addition to gasoline (T. Patzek, personal communication, University of California, Berkeley, 2004).

n) $20 \mathrm{~kg}$ of BOD per 1000 liters of ethanol produced [90].

p) Newton, 2001 [91].

q) DOE, $2002[92]$.

Manufacture of a liter of $99.5 \%$ ethanol uses $46 \%$ more fossil energy than it produces and costs $\$ 1.05$ per liter ( $\$ 3.97$ per gallon) (Table 5). The corn feedstock alone requires more than $33 \%$ of the total energy input.

The largest energy inputs in corn-ethanol production are for producing the corn feedstock plus the steam energy and electricity used in the fermentation/distillation process. The total energy input to produce a liter of ethanol is 7,474 $\mathrm{kcal}$ (Table 5). However, a liter of ethanol has an energy value of only 5,130 kcal. Based on a net energy loss of 2,344 kcal of ethanol produced, $46 \%$ more fossil energy is expended than is produced as ethanol. The total cost, including the energy inputs for the fermentation/distillation process and the apportioned energy costs of the stainless steel tanks and other industrial materials, is $\$ 1,045$ per 1000 liters of ethanol produced (Table 5).

The subsidies for corn ethanol total more than $\$ 6$ billion per year (Koplow, 2006). This means that the subsidies per liter of ethanol are 60 times greater than the subsidies per liter of gasoline. The actual crux of state behavior regarding ethanol rests on federal subsidies. A calculation of the environmental effects resulting from subsidizing ethanol production is difficult and the subsidy process itself is complex and fluid. The basic methodology of such calculations, however, should be to first identify:

a) the amount and type of ethanol that would be produced in the U.S. in the absence of subsidies and tariffs 
b) the amount and type of ethanol that would be consumed in the U.S. in the absence of subsidies and tariffs

c) the composition of energy that would most likely fill this void

d) the environmental costs and benefits of the current ethanol used in comparison to the environmental costs and benefits of the most likely alternative energy scenario.

These calculations assume that the behavior of Americans and their overall energy is an inelastic quantity, i.e. that energy consumption will neither increase nor decrease as a function of energy source. This assumption likely amounts to a conservative estimate of ethanol's environmental impact, as long as consumption behavior can be expected to constrict in the instance of a domestic shortage of energy, in other words, when a greater percentage of our energy comes from oil. The calculations also assume that Americans will follow an ideal-rational behavior model and, if given the option between purchasing ethanol and gasoline, will generally opt for whichever is cheaper. While there could be a non-economic, normative value to ethanol, this would be nearly impossible to calculate, and could just as easily exist as a normative value against ethanol.

In 2006, nearly 19 billion liters of ethanol were produced on $20 \%$ of U.S. corn acreage [27]. These 19 billion liters represents only $1 \%$ of total U.S. petroleum use.

However, even if we completely ignore corn ethanol's negative energy balance and high economic cost, we still find that it is absolutely not feasible to use ethanol as a replacement for U.S. oil consumption. If all 341 billion $\mathrm{kg}$ of corn produced in the U.S. [20] were converted into ethanol at a rate of $2.69 \mathrm{~kg}$ per liters of ethanol, then 129 billion liters of ethanol could be produced. This would provide only $7 \%$ of total oil consumption in the U.S. Of course, in this situation there would be no corn available for livestock or human consumption.

The environmental impacts of corn ethanol are enormous:

1) Corn production causes more soil erosion than any other crop grown [94].

2) Corn production uses more nitrogen fertilizer than any other crop grown and is the prime cause of the dead zone in the Gulf of Mexico [94]. In 2006, approximately 4.7 million tons of nitrogen was used in U.S. corn production [45]. In addition, about 1.7 million tons of phosphorus was used in the U.S. for corn production in 2006.

3) Corn production uses more insecticides than any other crop grown [95]. (Total: 7,530 kg used in corn in 2005 [96], or about $0.45 \mathrm{~kg} / \mathrm{ha}$.)

4) Corn production uses more herbicides than any other crop grown [77]. (Total: 186, $876 \mathrm{~kg}$ applied in 2005 [96], or $6.4 \mathrm{~kg} / \mathrm{ha}$.)

5) More than 1,700 gallons of water are required to produce 1 gallon of corn ethanol [97].

6) Enormous quantities of carbon dioxide are produced during corn ethanol production by the large quantity of fossil energy used in production, during fermentation, and when the soil is tilled, leaving soil organic matter exposed and oxidized. In addition, the conversion of cropland for biofuel production contributes to the release of greenhouse gases [98]. All this speeds global warming [99].

7) Related to the total operation, including the burning of the ethanol, the air pollution problem is significant [97, 100-102]. Burning ethanol emits pollutants into air such as peroxyacetyl nitrate 
(PAN), acetaldhyde, alkylates, and nitrous oxide. These can have significant human health effects, as well as impacts on other organisms and ecosystems [103].

\subsection{Grass and Cellulosic Ethanol}

Tilman et al. (2006) [104] suggest that all 235 million hectares of grassland, plus crop residues, can be converted into cellulosic ethanol. This is a suggestion that causes concern among scientists. Tilman et al. suggest that crop residues, like corn stover, can be harvested and utilized as a fuel source, but this would be a disaster for the agricultural ecosystem because crop residues are vital for protecting topsoil. Leaving the soil unprotected would intensify soil erosion by 10 -fold or more [105], and may increase soil loss as much as 100-fold [106]. Furthermore, even a partial removal of the stover can result in increased $\mathrm{CO}_{2}$ emissions and intensify acidification and eutrophication due to increased runoff [107,108]. Already, the U.S. crop system is losing soil 10 times faster than the sustainable rate [94]. Soil formation rates, at less than $1 \mathrm{t} / \mathrm{ha} / \mathrm{yr}$, are extremely slow [94,109]. Increased soil erosion caused by the removal of crop residues for use as biofuels will facilitate the soil-carbon oxidation and contribute to the greenhouse problem [110].

Tilman et al. [104] assume about 1,032 liters of ethanol can be produced through the conversion of the $4 \mathrm{t} / \mathrm{ha} / \mathrm{yr}$ of grasses harvested. However, Pimentel and Patzek (2008) [97] report a negative 68\% return in ethanol produced compared with the fossil energy inputs in switchgrass conversion (Tables 6 and 7). The cost of producing a liter of ethanol using switchgrass was $93 \not$ (Table 7). The two major energy inputs for switchgrass conversion into ethanol were steam and electricity production (Table 7).

Table 6. Average inputs and energy inputs per hectare per year for switchgrass production.

\begin{tabular}{llll} 
Input & Quantity & $\mathbf{1 0}^{\mathbf{3}}$ kcal & Dollars \\
\hline Labor & $5 \mathrm{hr}^{\mathrm{a}}$ & $200^{\mathrm{b}}$ & $\$ 65^{\mathrm{c}}$ \\
Machinery & $30 \mathrm{~kg}^{\mathrm{d}}$ & 555 & $50^{\mathrm{a}}$ \\
Diesel & $150 \mathrm{~L}^{\mathrm{e}}$ & 1,500 & 75 \\
Nitrogen & $80 \mathrm{~kg}^{\mathrm{e}}$ & 1,280 & $45^{\mathrm{e}}$ \\
Seeds & $1.6 \mathrm{~kg}^{\mathrm{f}}$ & $100^{\mathrm{a}}$ & $3^{\mathrm{f}}$ \\
Herbicides & $3 \mathrm{~kg}^{\mathrm{g}}$ & $300^{\mathrm{h}}$ & $30^{\mathrm{a}}$ \\
TOTAL & $10,000 \mathrm{~kg}$ yield & 3,935 & $\$ 268^{\mathrm{j}}$ \\
& 40 million kcal yield input/output ratio $1: 02^{\mathrm{k}}$ & \\
\hline
\end{tabular}
a) Estimated. Prorated this works out to be $200,000 \mathrm{kcal}$.
c) The agricultural labor is paid $\$ 13$ per hour.
d) The machinery estimate also includes $25 \%$ more for repairs.
e) Calculated based on data from Brummer et al., 2000 [111].
f) Data from Samson, 1991 [112].
g) Calculated based on data from Henning, 1993 [113].
h) $100,000 \mathrm{kcal}$ per $\mathrm{kg}$ of herbicide.
i) Samson et al., 2000 [114].

b) Average person works 2,000 hours per year and uses about 8,000 liters of oil equivalents. 
j) Brummer et al. 2000 [111] estimated a cost of about $\$ 400 /$ ha for switchgrass production. Thus, the $\$ 268$ total cost is about $49 \%$ lower than what Brummer et al. estimates and this includes several inputs not included in Brummer et al.

k) Samson et al. (2000) [114] estimated an input per output return of 1:14.9, but we have added several inputs not included in Samson et al. Still the input/output return of 1:11 would be excellent if the sustained yield of $10 \mathrm{t} / \mathrm{ha} / \mathrm{yr}$ were possible.

Table 7. Inputs per 1000 liters of $99.5 \%$ ethanol produced from U.S. switchgrass. ${ }^{\text {a }}$

\begin{tabular}{llll} 
Inputs & Quantity & kcal x 1000 & Dollars \$ \\
\hline Switchgrass & $5,000 \mathrm{~kg}^{\mathrm{b}}$ & $1,968^{\mathrm{c}}$ & 500 \\
S. Grass transport & $5,000 \mathrm{~kg}^{\mathrm{b}}$ & $600^{\mathrm{c}}$ & $30^{\mathrm{d}}$ \\
Water & $250,000 \mathrm{~L}^{\mathrm{e}}$ & $140^{\mathrm{f}}$ & $40^{\mathrm{m}}$ \\
Stainless steel & $3 \mathrm{~kg}^{\mathrm{g}}$ & $165^{\mathrm{g}}$ & $11^{\mathrm{g}}$ \\
Steel & $4 \mathrm{~kg}^{\mathrm{g}}$ & $92^{\mathrm{g}}$ & $11^{\mathrm{g}}$ \\
Cement & $8 \mathrm{~kg}^{\mathrm{g}}$ & $384^{\mathrm{g}}$ & $11^{\mathrm{g}}$ \\
Grind switchgrass & $5,000 \mathrm{~kg}$ & $200^{\mathrm{h}}$ & $16^{\mathrm{h}}$ \\
Sulfuric acid & $240 \mathrm{~kg}^{\mathrm{i}}$ & 0 & $168^{\mathrm{n}}$ \\
Steam & $8.1 \mathrm{tons}$ & 4,404 & 36 \\
Lignin & $1,250 \mathrm{~kg}^{\mathrm{j}}$ & minus 1,500 & minus 12 \\
Electricity & $666 \mathrm{kWh}^{\mathrm{i}}$ & 1,703 & 46 \\
95\% ethanol to $99.5 \%$ & $9 \mathrm{kcal} / \mathrm{L}^{\mathrm{k}}$ & 9 & 40 \\
Sewage effluent & $40 \mathrm{~kg} \mathrm{BOD}$ & $138^{\mathrm{o}}$ & 12 \\
Distribution & $331 \mathrm{kcal}^{\mathrm{j}} \mathrm{L}^{\mathrm{p}}$ & 331 & 20 \\
TOTAL & & 8,634 & $\$ 929$ \\
\hline
\end{tabular}

a) Output: 1 liter of ethanol $=5,130 \mathrm{kcal}$. The ethanol yield here is $200 \mathrm{~L} / \mathrm{t}$ dry biomass $(\mathrm{dbm})$. Iogen suggests $320 \mathrm{~L} / \mathrm{t} \mathrm{dbm}$ of straw that contains $25 \%$ of lignin. This yield is equal to the average yield of ethanol from corn, $317 \mathrm{~L} / \mathrm{t} \mathrm{dbm}(2.5 \mathrm{gal} / \mathrm{bu})$. In view of the difficulties with breaking up cellulose fibers and digesting them quickly enough, the Iogen yield seems to be exaggerated, unless significantly more grinding, cell exploding with steam, and hot sulfuric acid are used.

b) Data from table 6 .

c) Calculated for $144 \mathrm{~km}$ roundtrip.

d) Pimentel, 2003 [87].

e) 15 liters of water mixed with each $\mathrm{kg}$ of biomass.

f) Pimentel et al., 2004 [31].

g) Newton, 2001 [91].

h) Calculated based on grinder information [115].

i) Estimated based on cellulose conversion [116].

j) Wood is about $25 \%$ lignin and removing most of the water from the lignin by filtering, the moisture level can be reduced to $200 \%$ [117]. 
k) $95 \%$ ethanol converted to $99.5 \%$ ethanol for addition to gasoline (T. Patzek, personal communication, University of California, Berkeley, 2004).

1) $20 \mathrm{~kg}$ of BOD per 1000 liters of ethanol produced [90].

m) Pimentel, 2003 [87].

n) Sulfuric acid sells for $\$ 7$ per $\mathrm{kg}$.

o) $4 \mathrm{kWh}$ of energy required to process $1 \mathrm{~kg}$ of BOD (Blais et al., 1995) [88].

p) DOE, $2002[92]$.

Converting all 235 million ha of U.S. grassland into ethanol at the optimistic rate by Tilman et al. would provide only $12 \%$ of annual consumption of U.S. oil $[20,27]$. Sound data, however, confirm that the output in ethanol would require 1.5 liters of oil equivalents to produce 1 liter of ethanol (Tables 6 and 7). In addition, to achieve the production of this much ethanol, we would have to displace the 100 million cattle, 7 million sheep, and 4 million horses that are now grazing on 324 million ha of U.S. grassland and rangeland [20]. Already, overgrazing is a serious problem on U.S. grassland and a similar problem exists worldwide [118]. Thus, the assessment of the quantity of ethanol that can be produced on U.S. and world grasslands by Tilman et al. (2006) [104] appears to be unduly optimistic.

Several problems exist the conversion of cellulosic biomass into ethanol. First, it takes from 2 to 5 times more cellulosic biomass to achieve the same quantity of starches and sugars as are found in the same quantity of corn grain. Thus, 2 to 5 times more cellulosic material must be produced and handled compared with corn grain. In addition, the starches and sugars are tightly held in lignin in the cellulosic biomass. The starches and sugars can be released using a strong acid to dissolve the lignin. Once the lignin is dissolved the acid action is stopped with an alkali. Now the solution of lignin, starches, and sugars can be fermented.

Some claim that the lignin can be used as a fuel. Clearly, this would not be when dissolved in water. The lignin in the water mixture can be extracted using various energy intensive technologies. Usually less than $25 \%$ of the lignin can be extracted from the water mixture [97].

\subsection{Methanol}

Methanol can be produced from a gasifier-pyrolysis reactor using biomass as a feedstock [119,120]. The yield from 1 ton of dry wood is about 370 liters of methanol [121,122]. For a plant with economies of scale to operate efficiently, more than 1.5 million ha of sustainable forest would be required to supply this woody biomass annually [36]. However, biomass is not available in such enormous quantities, even from extensive forests, at acceptable prices for methanol to compete as a viable energy source. Most methanol today is produced from natural gas, not biomass [123]. About $10,402 \mathrm{kcal}$ are required to produce 1 liter of methanol that contains 7,430 kcal.

\subsection{Soybean Biodiesel}

Processed vegetable oils from soybean, sunflower, rapeseed, oil palm, and other oil plants can be used as fuel in diesel engines. Unfortunately, producing vegetable oils for use in diesel engines is costly in terms of economics and energy (Tables 8 and 9) [97,124]. A slight net return on energy from 
soybean oil is possible only if the soybeans are grown without commercial nitrogen fertilizer. The soybean, since it is a legume, will under favorable conditions produce its own nitrogen. Soy, however, has a $63 \%$ net fossil energy loss (Table 9).

Table 8. Energy inputs and costs in soybean production per hectare in the U.S.

\begin{tabular}{|c|c|c|c|}
\hline Inputs & Quantity & kcal x 1000 & Costs $\$$ \\
\hline Labor & $7.1 \mathrm{hrs}^{\mathrm{a}}$ & $284^{\mathrm{b}}$ & $112.00^{\mathrm{c}}$ \\
\hline Machinery & $20 \mathrm{~kg}^{\mathrm{d}}$ & $360^{\mathrm{e}}$ & $181.00^{\mathrm{f}}$ \\
\hline Diesel & $38.8 \mathrm{~L}^{\mathrm{a}}$ & $442^{\mathrm{g}}$ & 25.00 \\
\hline Gasoline & $35.7 \mathrm{~L}^{\mathrm{a}}$ & $270^{\mathrm{h}}$ & 16.00 \\
\hline LP gas & $3.3 \mathrm{~L}^{\mathrm{a}}$ & $25^{\mathrm{i}}$ & $1 . .00$ \\
\hline Nitrogen & $3.7 \mathrm{~kg}^{\mathrm{j}}$ & $59^{\mathrm{k}}$ & $28.00^{1}$ \\
\hline Phosphorus & $37.8 \mathrm{~kg}^{\mathrm{j}}$ & $156^{\mathrm{m}}$ & $29.00^{\mathrm{n}}$ \\
\hline Potassium & $14.8 \mathrm{~kg}^{\mathrm{j}}$ & $48^{\circ}$ & $6.00^{\mathrm{p}}$ \\
\hline Limestone & $2000 \mathrm{~kg}^{\mathrm{v}}$ & $562^{\mathrm{d}}$ & $56.00^{\mathrm{v}}$ \\
\hline Seeds & $69.3 \mathrm{~kg}^{\mathrm{a}}$ & $554^{\mathrm{q}}$ & $59.00^{\mathrm{r}}$ \\
\hline Herbicides & $1.3 \mathrm{~kg}^{\mathrm{j}}$ & $130^{\mathrm{e}}$ & 32.00 \\
\hline Electricity & $10 \mathrm{kWh}^{\mathrm{d}}$ & $29^{\mathrm{s}}$ & 1.00 \\
\hline Transport & $154 \mathrm{~kg}^{\mathrm{t}}$ & $40^{\mathrm{u}}$ & 56.00 \\
\hline TOTAL & & 2,959 & $\$ 602.00$ \\
\hline Soybean yield & $2,890 \mathrm{~kg} / \mathrm{ha}^{\mathrm{w}}$ & \multicolumn{2}{|c|}{10,404 kcal input:output $1: 3.52$} \\
\hline
\end{tabular}

a) Ali and McBride, 1990 [125].

b) It is assumed that a person works $2,000 \mathrm{hrs}$ per year and utilizes an average of 8,000 liters of oil equivalents per year.

c) It is assumed that labor is paid $\$ 13$ an hour.

d) Pimentel and Pimentel, 2008 [4].

e) Machinery is prorated per hectare and a 10 year life of the machinery. Tractors weigh from 6 to $7 \mathrm{t}$ and harvesters from 8 to 10 tons, plus plows, sprayers, and other equipment.

f) College of Agri., Consumer \& Environ. Sciences, 1997 [126].

g) Input $11,400 \mathrm{kcal}$ per liter.

h) Input $10,125 \mathrm{kcal}$ per liter.

i) Input 7,575 kcal per liter.

j) Economic Research Statistics, 1997 [127].

k) Patzek, 2004 [77].

1) Hinman et al., 1992 [128].

m) Input 4,154 kcal per kg.

n) Cost $77 \varnothing$ per kg.

o) Input $3,260 \mathrm{kcal}$ per $\mathrm{kg}$.

p) Costs $41 \varnothing$ per $\mathrm{kg}$. 
q) Pimentel et al., 2002 [129].

r) Costs about $85 \notin$ per $\mathrm{kg}$.

s) Input $860 \mathrm{kcal}$ per $\mathrm{kWh}$ and requires $3 \mathrm{kWh}$ thermal energy to produce $1 \mathrm{kWh}$ electricity.

t) Goods transported include machinery, fuels, and seeds that were shipped an estimated 1,000 $\mathrm{km}$.

u) Input $0.83 \mathrm{kcal}$ per $\mathrm{kg}$ per $\mathrm{km}$ transported.

v) Mississippi State University Extension Service, 1999 [130].

w) USDA, 2004 [131].

Table 9. Inputs per 1,000 kg of biodiesel oil from soybeans.

\begin{tabular}{llll} 
Inputs & Quantity & kcal x 1000 & Costs \$ \\
\hline Soybeans & $5,556 \mathrm{~kg}^{\mathrm{a}}$ & $5,689^{\mathrm{a}}$ & $1,157.00^{\mathrm{a}}$ \\
Electricity & $270 \mathrm{kWh}^{\mathrm{b}}$ & $697^{\mathrm{c}}$ & $18.90^{\mathrm{d}}$ \\
Steam & $1,350,000 \mathrm{kcal}^{\mathrm{b}}$ & $1,350^{\mathrm{b}}$ & $11.06^{\mathrm{e}}$ \\
Cleanup water & $160,000 \mathrm{kcal}^{\mathrm{b}}$ & $160^{\mathrm{b}}$ & $1.31^{\mathrm{e}}$ \\
Space heat & $152,000 \mathrm{kcal}^{\mathrm{b}}$ & $152^{\mathrm{b}}$ & $1.24^{\mathrm{e}}$ \\
Direct heat & $440,000 \mathrm{kcal}^{\mathrm{b}}$ & $440^{\mathrm{b}}$ & $3.61^{\mathrm{e}}$ \\
Losses & $300,000 \mathrm{kcal}^{\mathrm{b}}$ & $300^{\mathrm{b}}$ & $2.46^{\mathrm{e}}$ \\
Stainless steel & $11 \mathrm{~kg}^{\mathrm{f}}$ & $605^{\mathrm{g}}$ & $18.72^{\mathrm{h}}$ \\
Steel & $21 \mathrm{~kg}^{\mathrm{f}}$ & $483^{\mathrm{g}}$ & $18.72^{\mathrm{h}}$ \\
Cement & $56 \mathrm{~kg}^{\mathrm{f}}$ & $2,688^{\mathrm{g}}$ & $18.72^{\mathrm{h}}$ \\
TOTAL & & 12,564 & $\$ 1,251.74$
\end{tabular}

The $1,000 \mathrm{~kg}$ of biodiesel produced has an energy value of 9 million kcal. In addition, $200 \mathrm{ml}$ (2,080 $\mathrm{kcal}$ ) of methanol must be added to the soy oil for transesterification. With an energy input requirement of 14.7 million kcal, there is a net loss of energy of $63 \%$. If a credit of 7.4 million kcal is given for the soy meal produced, then the net loss is less.

The cost per kg of biodiesel is $\$ 1.25$.

a) Data from table 8 .

b) Data from Singh, 1986 [132].

c) An estimated $3 \mathrm{kWh}$ thermal is needed to produce a $\mathrm{kWh}$ of electricity.

d) Cost per $\mathrm{kWh}$ is $7 \phi$.

e) Calculated cost of producing heat energy using coal.

f) Calculated inputs.

g) Calculated from Newton, 2001 [91].

h) Calculated.

The U.S. provides $\$ 500$ million in subsidies for biodiesel for the production of 850 million liters of biodiesel [93], which is 74 times greater than the subsidies per liter of diesel fuel. As mentioned, the subsidies per liter of ethanol are 60 times greater than the subsidies per liter of gasoline. 
The environmental impacts of producing soybean biodiesel are second only to that of corn ethanol:

1) Soybean production causes significant soil erosion, is second only to corn production [94].

2) Soybean production uses large quantities of herbicides and is second only to corn production [133]. These herbicides cause major pollution problems with natural biota in the soybean production areas $[5,134]$.

Another important consideration in the use of soybeans as a potential biofuel source is cropland competition with food production. The USDA (2005) [96] reports a soybean yield worldwide of 2.2 tons per hectare. With an average oil extraction efficiency of $18 \%$ [135,136], the average oil yield per year would be approximately 0.4 tons per hectare. This converts into 454 liters of oil per hectare. Based on current U.S. diesel consumption of 227 billion liters/year [137], this would require more than 500 million hectares of land in soybeans or more than half the total U.S. planted just for soybeans! In other words, all 71 billion tons of soybeans produced in the U.S. [20] could only supply $2.6 \%$ of total U.S. oil consumption.

\subsection{Rapeseed and Canola Biodiesel}

The European Biodiesel Board estimates a total biodiesel production of 4.89 million tons for the year 2006 [138]. Well suited to colder climates, rapeseed is the dominant crop used in European biodiesel production. Often confused with canola, rapeseed is an inedible crop of the Brassica family, yielding oil seeds high in erucic acid. Canola is in the same family, but is a hybrid created to lower saturated fat content and erucic acid content for human consumption in cooking oil and margarine [137].

Frondel and Peters (2007) [139] describe rapeseed-based biodiesel yields in Europe averaging 1390 liters per hectare in 2005. Using the density of biodiesel defined as $0.88 \mathrm{~kg} / \mathrm{l}$ [139], it can be estimated that the average annual production of rapeseed biodiesel in Europe is 1.1 million tons total. Because of its high oil content (30\%), rapeseed is preferred as a biodiesel feedstock source [137]. While Europe currently dominates the rapeseed production in the world, as the market for high-yield oilseed feedstock for biodiesel grows, interest in canola and rapeseed oil is likely to increase in many northern states [137].

Rapeseed and canola require the application of fertilizers and pesticides in production. This disturbs the acid-base equilibrium of the soil and also can lead to algal blooms, as well as cause toxic pollution. Additionally, the energy required to make these pesticides and fertilizers detracts from the overall net energy produced [139]. Although soybeans contain less oil than canola, about $18 \%$ soy oil compared with $30 \%$ oil for rapeseed/canola, soybeans can be produced with nearly zero nitrogen inputs (Table 9). This makes soybeans more advantageous for the production of biodiesel, as nitrogen fertilizer is one of the most energy costly inputs in crop production [140].

The biomass yield of rapeseed/canola per hectare is also lower than that of soybeans - about 1,600 $\mathrm{kg} / \mathrm{ha}$ for canola compared with 2,890 kg/ha for soybeans (Tables 10 and 11) [131]. The production of $1,568 \mathrm{~kg} / \mathrm{ha}$ rapeseed/canola requires an input of about 4.4 million kcal per hectare and costs about $\$ 573 /$ ha (Table 10). About $3,333 \mathrm{~kg}$ of rapeseed/canola oil are required to produce $1,000 \mathrm{~kg}$ of biodiesel (Table 10). Therefore, all 333 million tons of rapeseed/canola produced in the U.S. in 2006 [141] could be used to make 100 million liters of biodiesel, or $0.005 \%$ of the total oil used in the U.S. 
The total energy input to produce the 1,000 liters of rapeseed/canola oil is 14 million kcal. This suggests a net loss of $58 \%$ of energy inputs (Table 11). The cost per $\mathrm{kg}$ of biodiesel is also high, at $\$ 1.63$. The subsidies for biodiesel are $\$ 500$ million for the production of 850 million liters of biodiesel [93]. Thus, the subsidies per liter of biodiesel are 74 times greater than the subsidies per liter of diesel fuel.

Table 10. Energy inputs and costs in canola production per hectare in the North America.

\begin{tabular}{llll} 
Inputs & Quantity & kcal x 1000 & Costs \$ \\
\hline Labor & $7 \mathrm{hrs}^{\mathrm{a}}$ & $280^{\mathrm{b}}$ & $91.00^{\mathrm{c}}$ \\
Machinery & $20 \mathrm{~kg}^{\mathrm{d}}$ & $360^{\mathrm{e}}$ & $148.00^{\mathrm{f}}$ \\
Diesel & $65 \mathrm{~L}^{\mathrm{a}}$ & $740^{\mathrm{g}}$ & 35.00 \\
Nitrogen & $120 \mathrm{~kg}^{\mathrm{a}}$ & $1,920^{\mathrm{h}}$ & $75.00^{\mathrm{i}}$ \\
Phosphorus & $101 \mathrm{~kg}^{\mathrm{a}}$ & $417^{\mathrm{j}}$ & $71.00^{\mathrm{k}}$ \\
Potassium & $14.8 \mathrm{~kg}^{\mathrm{l}}$ & $48^{\mathrm{m}}$ & $4.59^{\mathrm{n}}$ \\
Sulfur & $22 \mathrm{~kg}^{\mathrm{a}}$ & $10^{1}$ & 10.00 \\
Limestone & $1000 \mathrm{~kg}^{\mathrm{a}}$ & $281^{\mathrm{d}}$ & 23.00 \\
Seeds & $5 \mathrm{~kg}^{\mathrm{O}}$ & $40^{\mathrm{p}}$ & 35.00 \\
Herbicides & $1.5 \mathrm{~kg}^{\mathrm{q}}$ & $150^{\mathrm{p}}$ & 30.00 \\
Insecticides & $1 \mathrm{~kg}^{\mathrm{q}}$ & 100 & 20.00 \\
Electricity & $10 \mathrm{kWh}^{\mathrm{a}}$ & $29^{\mathrm{r}}$ & 0.70 \\
Transport & $100 \mathrm{~kg}^{\mathrm{s}}$ & $26^{\mathrm{t}}$ & 30.00 \\
TOTAL & & 4,401 & $\$ 573.29$ \\
Canola yield & $1,568 \mathrm{~kg}^{\mathrm{h}}$ & $5,645 \mathrm{kcal}$ input:output $1: 1.06$ \\
\hline
\end{tabular}

a) Smathers, 2005 [142].

b) It is assumed that a person works 2,000 hrs per year and utilizes an average of 8,000 liters of oil equivalents per year.

c) It is assumed that labor is paid $\$ 13$ an hour.

d) Pimentel and Pimentel, 1996 [143].

e) Machinery is prorated per hectare with a 10 year life of the machinery. Tractors weigh from 6 to $7 \mathrm{t}$ and harvesters from 8 to 10 tons, plus plows, sprayers, and other equipment.

f) College of Agri., Consumer \& Environ. Sciences, 1997 [126].

g) Input $11,400 \mathrm{kcal}$ per liter.

h) Patzek, 2004 [77].

i) Hinman et al., 1992 [128].

j) Input 4,154 kcal per $\mathrm{kg}$.

k) Cost $70 \varnothing$ per kg.

1) Pimentel and Pimentel, 2007 [9].

m) Input 3,260 kcal per $\mathrm{kg}$.

n) Costs $31 \notin$ per kg.

o) Molenhuis, 2004 [144].

p) Pimentel et al., 2002 [129]. 
q) Estimated.

r) Input $860 \mathrm{kcal}$ per $\mathrm{kWh}$ and requires $3 \mathrm{kWh}$ thermal energy to produce $1 \mathrm{kWh}$ electricity.

s) Goods transported include machinery, fuels, and seeds that were shipped an estimated 1,000 $\mathrm{km}$.

t) Input $0.83 \mathrm{kcal}$ per $\mathrm{kg}$ per $\mathrm{km}$ transported.

u) USDA, 2004 [131].

Table 11. Inputs per $1,000 \mathrm{~kg}$ of biodiesel oil from canola.

\begin{tabular}{llll} 
Inputs & Quantity & kcal x 1000 & Costs \$ \\
\hline Canola & $3,333 \mathrm{~kg}^{\mathrm{a}}$ & $9,355^{\mathrm{a}}$ & $\$ 1,419.00^{\mathrm{a}}$ \\
Electricity & $270 \mathrm{kWh}^{\mathrm{b}}$ & $697^{\mathrm{c}}$ & $18.90^{\mathrm{d}}$ \\
Methanol & $120 \mathrm{~L}^{\mathrm{i}}$ & $1,248^{\mathrm{i}}$ & 111.60 \\
Steam & $1,350,000 \mathrm{kcal}^{\mathrm{b}}$ & $1,350^{\mathrm{b}}$ & $11.06^{\mathrm{e}}$ \\
Cleanup water & $160,000 \mathrm{kcal}^{\mathrm{b}}$ & $160^{\mathrm{b}}$ & $1.31^{\mathrm{e}}$ \\
Space heat & $152,000 \mathrm{kcal}^{\mathrm{b}}$ & $152^{\mathrm{b}}$ & $1.24^{\mathrm{e}}$ \\
Direct heat & $440,000 \mathrm{kcal}^{\mathrm{b}}$ & $440^{\mathrm{b}}$ & $3.61^{\mathrm{e}}$ \\
Losses & $300,000 \mathrm{kcal}^{\mathrm{b}}$ & $300^{\mathrm{b}}$ & $2.46^{\mathrm{e}}$ \\
Stainless steel & $11 \mathrm{~kg}^{\mathrm{f}}$ & $158^{\mathrm{g}}$ & $18.72^{\mathrm{h}}$ \\
Steel & $21 \mathrm{~kg}^{\mathrm{f}}$ & $246^{\mathrm{g}}$ & $18.72^{\mathrm{h}}$ \\
Cement & $56 \mathrm{~kg}^{\mathrm{f}}$ & $106^{\mathrm{g}}$ & $18.72^{\mathrm{h}}$ \\
TOTAL & & 14,212 & $\$ 1,625.34$
\end{tabular}

The $1,000 \mathrm{~kg}$ of biodiesel produced has an energy value of 9 million $\mathrm{kcal}$. The methanol input is a required addition to the canola oil for transesterification. With a total energy input requirement of 14.2 million kcal, there is a net loss of energy of 58\%. If a credit of 4.6 million kcal is given for the canola meal produced, then the net loss is less.

The cost per kg of biodiesel is $\$ 1.63$.
a) Data from Table 10.
b) Data from Singh, 1986 [132].
c) An estimated $3 \mathrm{kWh}$ thermal is needed to produce a $\mathrm{kWh}$ of electricity.
d) Cost per $\mathrm{kWh}$ is $7 \phi$.
e) Calculated cost of producing heat energy using coal.
f) Calculated inputs.
g) Calculated from Newton, 2001 [91].
h) Calculated.
i) Hekkert et al., 2005 [123].

\subsection{Oil Palm}

There is a major effort to plant and harvest oil palms for biofuels in some tropical developing countries, especially Indonesia, Malaysia, Thailand, Colombia, and some in West Africa [145]. In the last 20 years, the production of vegetable oil has more than doubled. 
Palm oil makes up 30\%, over 35\% when including palm kernel oil, of biological oils and fats produced worldwide [146]. Global oil palm production for the U.S. Department of Agricultures' 20072008 growing season totaled more than 45.3 million tons; of which about 4.7 million metric tons was palm kernel oil [146]. Indonesia and Malaysia are the world's leading producers. Together these countries total over $84 \%$ of global palm oil production [147]. Relative to the world total agricultural oil, over $84 \%$ is palm oil production [147]. Relative to world total agricultural oil export, both Indonesia and Malaysia lead country exports with $15 \%$ and $14 \%$ respectively, the dominant majority of which is palm oil [146].

The oil palm once established (after 4 years) will produce about 4,000 $\mathrm{kg}$ of oil per hectare per year [148]. The energy inputs for maintaining the hectare of oil palm are indicated in Table 12. The data suggest that about 7.4 million $\mathrm{kcal}$ are required to produce $26,000 \mathrm{~kg}$ of palm oil bunches. This 26,000 $\mathrm{kg}$ is a sufficient quantity of palm nuts to produce $4,000 \mathrm{~kg}$ of palm oil. A total of 6.9 million kcal are required to process $6,500 \mathrm{~kg}$ of palm nuts to produce 1 ton of palm oil (Table 13). Thus, the net return on fossil energy invested in production and processing totals $30 \%$, which is clearly a better return than corn ethanol and soybean biodiesel. However, an estimated $200 \mathrm{ml}(2,080 \mathrm{kcal})$ of methanol is a required addition to the $1,000 \mathrm{~kg}$ of palm oil, for transesterification. This results in a negative $8 \%$ net energy output for palm oil (Table 13).

Table 12. Energy inputs for palm oil production in Thailand and Indonesia.

\begin{tabular}{lll} 
Inputs & Quantity & kcal x 1000 \\
\hline Labor & $1,000 \mathrm{hrs}^{\mathrm{a}}$ & $700^{\mathrm{b}}$ \\
Machinery & $55 \mathrm{~kg}^{\mathrm{c}}$ & $1,018^{\mathrm{c}}$ \\
Diesel & $130 \mathrm{~L}^{\mathrm{d}}$ & $1,430^{\mathrm{e}}$ \\
Nitrogen & $150 \mathrm{~kg}^{\mathrm{d}}$ & $2,400^{\mathrm{f}}$ \\
Phosphorus & $81 \mathrm{~kg}^{\mathrm{d}}$ & $336^{\mathrm{g}}$ \\
Potassium & $206 \mathrm{~kg}^{\mathrm{d}}$ & $672^{\mathrm{h}}$ \\
Magnesium & $56 \mathrm{~kg}^{\mathrm{d}}$ & $400^{\mathrm{a}}$ \\
Irrigation & $8 \mathrm{~cm}^{\mathrm{d}}$ & $320^{\mathrm{a}}$ \\
Herbicides & $4.0 \mathrm{~kg}^{\mathrm{d}}$ & $400^{\mathrm{i}}$ \\
Insecticides & $1.0 \mathrm{~kg}^{\mathrm{d}}$ & $100^{\mathrm{j}}$ \\
Transport & $200 \mathrm{~kg}^{\mathrm{a}}$ & $166^{\mathrm{k}}$
\end{tabular}

Total

Palm Oil Bunches $26,000 \mathrm{~kg}^{\mathrm{d}}$

a) Estimated.

b) BP World Energy, 2005 [29].

c) Estimated.

d) Pleanjai et al., 2004 [149].

e) $11,430 \mathrm{kcal}$

f) $16,000 \mathrm{kcal} / \mathrm{kg}$

g) $4,154 \mathrm{kcal} / \mathrm{kg}$ 
h) $3,260 \mathrm{kcal} / \mathrm{kg}$

i) $100,000 \mathrm{kcal} / \mathrm{kg}$

j) $100,000 \mathrm{kcal} / \mathrm{kg}$

k) Calculated.

Table 13. Inputs per 6.5 tons of palm nuts that produces 1 ton of palm oil [149].

\begin{tabular}{lll} 
Inputs & Quantity & kcal x 1000 \\
\hline Palm nuts & $6,500 \mathrm{~kg}^{\mathrm{a}}$ & $1,861^{\mathrm{a}}$ \\
Palm nuts transport & $6,500 \mathrm{~kg}^{\mathrm{b}}$ & $332^{\mathrm{c}}$ \\
Water & $30,000 \mathrm{~L}^{\mathrm{d}}$ & $68^{\mathrm{e}}$ \\
Stainless steel & $3 \mathrm{~kg}^{\mathrm{f}}$ & $165^{\mathrm{e}}$ \\
Steel & $4 \mathrm{~kg}^{\mathrm{f}}$ & $92^{\mathrm{e}}$ \\
Cement & $8 \mathrm{~kg}^{\mathrm{f}}$ & $384^{\mathrm{e}}$ \\
Steam & $3,000,000 \mathrm{kcal}^{\mathrm{d}}$ & $3,000^{\mathrm{d}}$ \\
Electricity & $380 \mathrm{kWh}^{\mathrm{d}}$ & $980^{\mathrm{d}}$ \\
Sewage effluent & $9 \mathrm{~kg} \mathrm{BOD}^{\mathrm{g}}$ & $31^{\mathrm{h}}$ \\
& & \\
Total & & $6,913 \mathrm{i}$ \\
Energy content of 1 ton of palm oil & 8,300 \\
\hline
\end{tabular}

a) Data from table 12 .

b) Factory located $144 \mathrm{~km}$ away.

c) Calculated.

d) Plaenjai et al., 2004 [149].

e) Estimated.

f) From Pimentel and Patzek, (2007) [38].

g) Plaenjai et al., 2004 [149].

h) $4 \mathrm{kWh}$ of energy required to process $1 \mathrm{~kg}$ of BOD.

i) An estimated $200 \mathrm{ml}(2,080 \mathrm{kcal})$ was added to the $1,000 \mathrm{~kg}$ of palm oil for transesterification. This results in a negative $8 \%$ net energy output for palm oil.

There are several environmental and social issues associated with oil palm plantations. In major palm oil producing countries the creation of new plantations represents the greatest loss of natural forests and mixed agro-forestry systems [150]. Additionally, the removal of tropical rainforests to plant the oil palm results in an increase in $\mathrm{CO}_{2}$. The amount of $\mathrm{CO}_{2}$ released increases tremendously when burning is used to clear forest [145]. Furthermore, the removal of natural and mixed agroforestry systems and the planting of oil palms reduces the biodiversity of the local ecosystem; species composition of vertebrate taxa changed up to $60 \%$ in some instances [150]. The degree of loss is compounded with larger plantation sizes; individual monoculture oil palm plantations can reach sizes up to 20,000 ha [150]. Moreover, pollution in processing oil palm is quite substantial. Mill waste entering water bodies is equivalent to that generated by an estimated 1.5 million people [150]. Finally, the increased use of oil palm for fuel reduces the availability of the oil and increases the price for 
human use [145]. Oil Palm production has a better net fossil energy return than many competing biofuel crops. However, production is accompanied by various social, health, and environmental consequences.

\subsection{Jatropha}

Jatropha is receiving a great deal of attention now as new source of biodiesel. The shrub, endemic to Mexico [151], produces seeds that are 30\% oil, which is excellent for biofuel use. The shrub will grow in heavy rainfall regions as well as in arid regions. In arid regions, the yield is reduced to only 0.5 tons/ha per year [152]. A potential benefit of Jatropha is that it cannot be used for a food crop. This allows the plant to be grown only for fuel. The most serious drawback to the shrub as a biofuel is that it is highly toxic to humans and livestock, plus it uses land and water resources that are critical for food crop production [153]. Therefore, further research is necessary to evaluate the long-term safety of producing, handling, and processing this feedstock.

\section{Algae for Oil Production}

Some cultures of algae consist of $30 \%$ to $50 \%$ oil [154]. Thus, there is growing interest using algae to increase U.S. oil supply based on the theoretical claims that 47,000 to 308,000 liters/hectare/year (5,000 to 33,000 gallons/acre) of oil could be produced using algae [155,156]. The calculated cost per barrel would be $\$ 15$ [157]. Currently, oil in the U.S. market is selling for over $\$ 100$ per barrel. If the production and price of oil produced from algae were true, U.S. annual oil needs could theoretically be met if $100 \%$ of all U.S. land were in algal culture!

Despite all the algae-related research and claims dating back to 1970's, none of the projected algae and oil yields has been achieved [154]. To the contrary, one calculated estimate based on all the included costs using algae would be $\$ 800$ per barrel, not $\$ 15$ per barrel, as mentioned. Algae, like all plants, require large quantities of nitrogen fertilizer and water. In addition, significant fossil energy inputs would be needed for the functioning production system [158].

One difficulty in culturing algae is that the algae shade one another's cells. There are, therefore, different levels of light saturation in the cultures, even under optimal conditions such as in Florida [159]. These differences influence the rate of growth of the algae. In addition, wild strains of algae sometimes invade and dominate the algae culture strains, causing a decrease in oil production by the algae [159].

Another major problem with the culture of algae in ponds or tanks, is the harvesting of the algae. Since algae consist mostly of water, harvesting algae from the cultural tanks and separating the oil from the algae are difficult and energy intensive processes. This problem was observed at the University of Florida (Gainesville) when algae were being cultured in managed ponds for the production of nutrients for hogs. After two years, the unsuccessful algal-nutrient culture was abandoned.

The best algal biomass yields under tropical conditions are about $50 \mathrm{t} / \mathrm{ha} / \mathrm{yr}$ [159]. However, the highest yield of alga biomass produced per hectare, based on theoretical calculation, is 681 tons/ha/yr [156]. For comparison, the total yield for rice (including rice and straw) grown in the tropics is nearly 
$50 \mathrm{t} / \mathrm{ha} / \mathrm{yr}$ of continuous culture [160]. Rice production in the tropics can produce 3 crops on the same hectare of land per year requiring about $400 \mathrm{~kg} / \mathrm{ha}$ of nitrogen fertilizer and 240 million liters of water [160]. Obviously, a great deal of laboratory and field research is needed for the algae and oil theoretical system.

\section{Impacts of Culturing Crops and Grasses for Biofuels}

Managing crops and grasses for biofuels results in many and varied environmental impacts to the land, water, and biodiversity. Some impacts of biofuel crop production on soil erosion and air pollution are discussed below.

\subsection{Soil Erosion Associated with Biofuels}

Soil erosion and land degradation are of particular concern to agriculturalists and foresters because of increasing biofuel production. Serious soil erosion is taking place in U.S. agricultural systems, with an estimated soil loss that is 11 times faster than a sustainable rate [161]. The prime cause of high erosion rates in the U.S. is due to the depletion of biomass cover that protects the soil from rainfall and wind energy. In particular, row crops such as corn and soybeans are particularly susceptible to erosion [5]. Tilling the soil for planting of row crops leaves the soil unprotected from wind and rainfall. After harvesting, soybeans have little crop residue which covers only $20 \%$ of the cropland. Corn stover covers about $60 \%$ of the land after harvest [162].

The intensive application of nitrogen fertilizers in corn production was perceived to sequester soil organic carbon in the soil. However, after a 40 to 50 year application of synthetic nitrogen fertilizer in Illinois, a net decline occurred in soil carbon despite the massive residue incorporation into the soil [163].

Some investigators, like Tilman et al. (2006) [104] and Perlack et al. (2005) [164], suggest that crop residues can be harvested for biofuel production. If this is done, soil erosion, with the removal of crop residues, will increase from 10-fold to 100-fold [165]. Removing crop residues would therefore devastate U.S. agriculture.

Close grown crops, like wheat with an average yield of $7 \mathrm{t} / \mathrm{ha} / \mathrm{yr}$, protect the soil from erosion with an erosion rate of about $5 \mathrm{t} / \mathrm{ha} / \mathrm{yr}$. This is better than the soil erosion rate of row crops, like corn, with an average soil erosion rate of $15 \mathrm{t} / \mathrm{ha} / \mathrm{yr}$ [109]. After germinating, spring wheat has an early, fast growing development of a relatively dense stand of vegetation cover of 150 to 200 plants $/ \mathrm{m}^{2}$ that is capable of protecting the soil from rain and wind energy. Unfortunately, wheat is not a good biofuel crop because of its low yield [20].

Some crops, such as grass, provide nearly complete cover of the soil once established. These crops are usually grown as perennials and cover the soil all year for about 5-year periods. The soil erosion rate from continuous grass is reported to lose soil at only 0.1 to $1 \mathrm{t} / \mathrm{ha} / \mathrm{yr}$ [110]. Yet, grass and other such crops are unfortunately not generally productive as biofuel crops.

Some biofuel crops, like sugarcane, have high soil erosion rates, which are reported to be about 148 t/ha/yr in Australia [166]. 
No-till and ridge-till planting of corn and similar crops will reduce the soil erosion rates from 18 t/ha/yr to $2 \mathrm{t} / \mathrm{ha} / \mathrm{yr}$ [167]. Herbicides and other pesticides are needed in no-till corn production, but with ridge-till herbicides may not be necessary.

In addition, the water-holding capacity and nutrient levels of the soil decline when erosion occurs. With conventional corn production, erosion reduced the volume of moisture in the soil about $50 \%$ compared with organic corn production [168].

When conservation technologies, like organic agriculture, are employed, increased yields may result because water, nutrients, and soil organic matter are retained. For example, in Pennsylvania, yields of corn and soybeans were $33 \%$ to $50 \%$ higher in the organic systems when soil organic matter increased in the organic systems over time even when drought conditions occurred [168].

In the U.S., annual estimates of soil loss were estimated to be 1 to 2 billion tons per year, and 10 years later the erosion rate had increased to 3 billion tons annually [169].

Undisturbed forests often have a dense cover over the soil consisting of leaves, twigs, and other organic matter; these forest ecosystems have soil erosion rates that typically range from less than 0.1 $\mathrm{t} / \mathrm{ha} / \mathrm{yr}$ to $0.2 \mathrm{t} / \mathrm{ha} / \mathrm{yr}$ [5]. The combination of organic mulch, tree cover, and tree roots makes most natural forest soils, even on steep slopes of $70 \%$, resistant to erosion and rapid water runoff. Forests lose significant quantities of water, soil, and nutrients when cut and harvested [170]. In addition, erosion rates increase. Therefore, the use of forests for producing biofuels will increase rates of soil erosion. However, short-rotation woody-crops have been shown to improve groundwater quality and soil-water runoff in comparison to row crops [171].

\subsection{Air Pollution}

Smoke produced when fuelwood and crop biomass are burned is a serious pollution hazard because of the nitrogen, particulates, and other chemicals in the smoke. Although only $3 \%$ of U.S. heating energy comes from wood, about $15 \%$ of the air pollutants in the U.S. are produced from the burning of wood [172]. Emissions from burning wood and other biomass are a threat to public health because of the highly respirable nature of the more than 200 chemicals that the emissions contain [173].

Of special concern are the relatively high concentrations of potentially carcinogenic poly cyclic organic compounds (POMs, e.g. benzo $\{$ a $\}$ pyrene) and particulates. Sulfur and nitrogen oxides, carbon monoxide, and aldehydes are also released, but usually in smaller quantities. According to Naeher et al. (2007) [173], wood smoke contains an estimated 14 carcinogens and 4 co-carcinogens. Great concern is expressed for the 4 billion people in developing countries who cook and heat with wood and crop residues [6].

The burning of ethanol in automobiles also causes major pollution problems. Ethanol has only $66 \%$ of the energy that gasoline has and, therefore, significantly more fuel has to be burned to travel the same distance as gasoline [97]. In addition, ethanol produces more nitrous oxides and ozone than gasoline as measured from the exhausts of automobiles [100,101]. These are serious air pollutants affecting human health, and these pollutants and their impact on human health were recently confirmed in new studies by Jacobson [102].

In addition, ethanol and other biofuels exacerbate the current global warming situation worse. Nobel chemist Paul J. Crutzen [174] reported that biofuels made from corn and rapeseed release about twice as many nitrous oxides as previously reported. The authors of the report from the University of 
Edinburg, conclude that growing biofuels is probably of no benefit and is actually making the climate situation worse.

\section{Conclusion}

The rapidly growing world population and rising consumption of fossil fuels is increasing demand for both food and biofuels. This will exaggerate both food and fuel shortages. Producing biofuels requires huge amounts of both fossil energy and food resources, which will intensify conflicts among these resources.

Using food crops such as corn grain to produce ethanol raises major nutritional and ethical concerns. Nearly $60 \%$ of humans in the world are currently malnourished, so the need for grains and other basic foods is critical [7]. Growing crops for fuel squanders land, water, and energy resources vital for the production of food for people. Using corn for ethanol increases the price of U.S. beef, chicken, pork, eggs, breads, cereals, and milk from $10 \%$ to $30 \%$ [175]. In addition, Jacques Diouf, Director General of the U.N. Food and Agriculture Organization, reports that using food grains to produce biofuels is already causing food shortages for the poor of the world [176,177]. Growing crops for biofuel not only ignores the need to reduce natural resource consumption, but exacerbates the problem of malnourishment worldwide by turning precious grain into biofuel.

Recent policy decisions have mandated increased production of biofuels in the United States and worldwide. For instance, in the Energy Independence and Security Act of 2007, President Bush set "a mandatory Renewable Fuel Standard (RFS) requiring fuel producers to use at least 36 billion gallons of biofuel in 2022." This would require 1.6 billion tons of biomass harvested per year and would require harvesting $80 \%$ of all biomass in the U.S., including all agricultural crops, grasses, and forests (Table 3). With nearly total biomass harvested, biodiversity and food supplies in the U.S. would be decimated!

The release of large quantities of carbon dioxide associated with the planting and processing of plant materials for biofuels is reported to reduce the nutritional quality of major world foods, including corn, wheat, rice, barley, potatoes, and soybeans. When crops are grown under high levels of carbon dioxide, protein levels in the crops may be reduced as much as $15 \%$ [178].

Many problems associated with biofuels have been ignored by scientists and policy makers. For one, the biofuels that are being created in order to diminish the dependence on fossil fuels, actually depend on fossil fuels. In most cases, more fossil energy is required to produce a unit of biofuel compared with the energy that is produced (Tables $4-11$ ). Furthermore, the U.S. is importing oil and natural gas to produce biofuels, which is not making the U.S. oil independent. Secondly, some publications use incomplete or insufficient data to support the claims of the pro-biofuel publications. For instance, claims that cellulosic ethanol provides net energy [104] have not been experimentally verified because most of the calculations are theoretical. Finally, environmental problems such as water pollution from fertilizers and pesticides, global warming, soil erosion and air pollution are intensifying with biofuel production. There is simply not enough land, water, and energy to produce biofuels.

Based on careful up-to-date analysis of all fossil energy inputs, most conversions of biomass into ethanol and biodiesel result in a negative energy return. Four of the negative energy returns are: corn 
ethanol (minus 48\%); switchgrass (minus 68\%) soybean biodiesel (minus 63\%); and rapeseed (minus $58 \%$ ). Conversely, palm oil production in Thailand suggests a positive $30 \%$ energy return.

Some balance and improvement in the food and biofuel situation is possible. There is desperate need for petroleum and natural gas conservation as well as sound soil, water, and biological resource conservation. There are many opportunities for implementing known sustainable agricultural and forestry technologies. These include:

1) Soil conservation by leaving crop residues on the surface of the soil. Planting cover crops after the main crop, like corn has been harvested. Other soil conservation technologies that should be employed when possible are: planting on the contour; planting on terraces; using grass strips; crop rotations; mulches; and similar technologies and combinations.

2) Water conservation is vital because of the enormous amounts of water crops utilize. In addition to soil conservation technologies, increasing the organic matter in the soil will increase the water holding capacity significantly and will increase the number and abundance of soil biota.

3) Planting trees as hedge-rows and wind breaks can significantly reduce soil loss, water runoff, and evaporation.

4) Maintaining forest stands will conserve soil, water, biodiversity in the ecosystem.

Because the green plants in the U.S. collect a total of only 32 quads of solar energy per year, they cannot provide the nation with a replacement of the more than 100 quads of fossil energy use per year. This means that even if all available crops, forests, and grasses were harvested for biofuel, we would still be dependent on oil and natural gas supplies, which are projected to disappear in about 40 years. U.S. citizens should reduce their per capita energy use by one-half because this change will become a reality when oil and natural gas supplies disappear in about 40 years. Instead of subsidizing corn ethanol and soybean biodiesel by more than $\$ 10$ billion per year, these funds should be invested in research in renewable energy technologies.

\section{Acknowledgements}

The authors wish to thank Holli Edgley and Elizabeth Keokosky at Cornell University for their contributions to the development of this paper. We are also grateful to the following people for their comments and suggestions on earlier versions of the paper: Harry de Gorter, Department of Applied Economics and Management, Cornell University, Ithaca, NY; Marcelo Dias De Oliveira, Rice University, Houston, TX; Andrew Ferguson, Optimum Population Trust, Manchester, UK; Mario Giampietro, Universitat Autonoma de Barcelona, Spain; David Hammer, Electrical and Computer Engineering, Cornell University, Ithaca, NY; Roel Hammerschlag, Climate and Energy Program, Stockholm Environment Institute (U.S.), Somerville, MA; Conly Hansen, Director Center for Profitable Uses of Agricultural, Utah State University, Logan, UT; Phillip McMichael, Development Sociology, Cornell University, Ithaca, NY; Rattan Lal, Ohio State University, Columbus, OH; Michele Whitecraft, Cornell University, Ithaca, NY; Walter Youngquist, Petroleum Consultant, Eugene, OR. In addition, we offer our sincere gratitude to the Cornell Association of Professors Emeriti for the partial support of our research through the Albert Podell Grant Program. 


\section{References}

1. Barbara, J.S. The False Promise of Biofuels. Special Report from the International Forum on Globalization and the Institute for Policy Studies. 2007, 30 pages. http://www.ifg.org/pdf/biofuels.pdf

2. Cleveland, C.J.; Costanza, R.; Hall, C.A.S.; R. Kaufmann, R. Energy and the United States Economy: A Biophysical Perspective. Science 1983, 225, 890-897.

3. Hall, C.A.S.; Cleveland, C.J.; Kaufmann, R. Energy and Resource Quality: The Ecology of the Economic Process. Wiley Interscience: New York, 1986. 577 pp.

4. Pimentel, D.; Pimentel, M. Food, Energy and Society. CRC Press. Taylor and Francis Group, Boca Raton, Florida, 2008.

5. Pimentel, D. Soil Erosion: A Food and Environmental Threat. Environment, Development and Sustainability 2006, 8, 119-137.

6. Pimentel, D.; Cooperstein, S.; Randell, H.; Filiberto, D.; Sorrentino, S.; Kaye, B.; Nicklin, C.; Yagi, J.; Brian, J.; O’Hern, J.; Habas, A.; Weinstein, C. Ecology of Increasing Diseases: Population Growth and Environmental Degradation. Human Ecology 2007, 35 (6), 653-668.

7. WHO. 2005. Malnutrition Worldwide. World Health Organization. http://www.mikeschoice.com/reports/malnutrition_worldwide.htm. (12/7/07).

8. FAO. Food and Agricultural Organization of the United Nations. 1961-2006. FAO: Rome.

9. Pimentel, D.; Pimentel, M. Ecological Engineering: Growth of Human Population. Encyclopedia of Ecology. Elsevier, 2007. In Press.

10. Pimentel, D.; Gardner, J.B.; Bonnifield, A.J.; Garcia, X.; Grufferman, J.B.; Horan, C. M.; Rochon, E.T.; Schlenker, J.L.; Walling, E.E. Energy Efficiency and Conservation for Individual Americans. Environment, Development and Sustainability 2008, DOI 10.1007/s10668-007-9128$\mathrm{x}$.

11. Nonhebel, S. Renewable Energy and Food Supply: Will There Be Enough Land? Renewable and Sustainable Energy Reviews 2005, 9 (2), 191-201.

12. PRB. World Population Data Sheet, 2007. Population Reference Bureau: Washington, DC.

13. USDA. 1980-2006. Agricultural Statistics. U.S. Department of Agriculture. Washington, DC.

14. Sommer, A.; West, K.P. Vitamin A Deficiency: Health, Survival and Vision. Oxford University Press, New York, 1996.

15. Tomashek K.M.; Woodruff, B.A.; Gotway, C.A.; Bloland, P.; Mbaraku, G. Randomized Intervention Study Comparing Several Regimens for the Treatment of Moderate Anemia among Refugee Children in Kigoma Region, Tanzania. American Journal of Tropical Medicine and Hygiene 2001, 64, 164-171.

16. Environment News Service. 850 Million Still Hungry on World Food Day. 2002. http://www.ens-newswire.com/ens/oct2002/2002-10-16-03.asp. (11/4/07).

17. Svedberg, P. Poverty and Undernutrition: Theory, Measurement, and Policy. Oxford University Press: New York, 2000.

18. Bryce, J.; Boschi-Pinto, C.; Shibuya, K.; Black, R.E. WHO Estimates of the Causes of Death in Children. The Lancet 2005, 365 (9465), 1147-1152. 
19. Kirby, A. UN Warns of Future Water Crisis. BBC News Online (March 5, 2003).m http://news.bbc.co.uk/2/hi/science/nature/2818615.stm/ (4/5/08).

20. USDA. Agricultural Statistics, 2006. U.S. Department of Agriculture. U.S. Government Printing Office: Washington, DC, 2006.

21. Blair, D.; Sobal, J. Luxus Consumption: Wasting Food Resources Through Overeating. Agriculture and Human Values 2006, 23, 63-74.

22. FAO. The Salt of the Earth: Hazardous for Food Production. Food and Agricultural Organization of the United Nations. World Food Summit. 2002.

http://www.fao.org/WorldFoodSummit/english/newsroom/focus/focus1.htm. (3/09/08).

23. FAOSTAT. Food and Agricultural Organization. 2001. United Nations: Rome.

24. UN. 1999. Population Division. Department of Economics and Social Affairs. United Nations Secretariat. The World at Six Billion. Part 1.

http://www.un.org/esa/population/publications/sixbillion/sixbilpart1.pdf. (11/4/07).

25. IWMI. Global Irrigated Area. International Water Management Institute. 2007. http://www.iwmigiam.org/stats. (3/09/08).

26. Giampietro, M.; Pimentel, D. Energy Utilization. In Encyclopedia of Agricultural Science. Arntzen, C.J.; Ritter, E.M., Eds.; Academic Press: San Diego, CA, 1994; Vol. 2, 63-76.

27. USCB. Statistical Abstract of the United States, 2007. U.S. Census Bureau, U.S. Government Printing Office: Washington, DC.

28. Pimentel, D.; Wen, D. China and the World: Population, Food and Resource scarcity. In Dare to Dream: Vision of 2050 Agriculture in China; Tso, T.C. and Kang, H., Eds.; China Agricultural University Press: Beijing, 2004, Chapter 8, 103- 16.

29. BP. BP Statistical Review of World Energy. British Petroleum: London, 2005, 41 pages.

30. Gleick, P.H. Basic Water Requirements for Human Activities: Meeting Basic Needs. Water International 1996, 21, 83-92.

31. Pimentel, D.; Berger, B.; Filberto, D.; Newton, M.; Wolfe, B.; Karabinakis, E.; Clark, S.; Poon, E.; Abbett, E.; Nandagopal, S. Water Resources: Current and Future Issues. BioScience, 2004, 54 (10), 909-918.

32. FAO. Agriculture, Food and Water. Chapter 2: How the World is Fed. FAO Corporate Document Repository. 2001. Food and Agricultural Organization of the United Nations. http://www.fao.org/docrep/006/y4683e/y4683e06.htm (8/28/08).

33. Youngquist, W.; Duncan, R.C. North American Gas: Data Show Supply Problems. Natural Resources Research 2003, 12 (4), 229-240.

34. Campbell, C. Excel Spread Sheets of Oil and Gas of Production and Discovery. Oil Depletion Analysis Centre: London, England, 2006.

35. Heinberg, R. Oil Apocalypse: What happens when demand for oil outstrips Supply? 2007. http://www.richardheinberg.com/ (1/29/08).

36. Pimentel, D. 2001. The Limitations of Biomass Energy. In Encyclopedia of Physical Science and Technology. $3^{\text {rd }}$ ed.; Meyers, R., Ed.; Academic Press, San Diego, 2001; Vol. 2, 159-171.

37. Flow of Energy. Primary Production. 2005. http://www.globalchange.umich.edu/globalchange1/current/lectures/kling/energyflow.html. $(12 / 17 / 06)$. 
38. Pimentel, D.; Patzek, T. Ethanol Production: Energy and Economic Issues Related to U.S. and Brazilian Sugarcane. Natural Resources Research 2007, 16 (3), 235- 42.

39. Jölli, D.; Giljum, S. 2005. Unused Biomass Extraction in Agriculture, Forestry and Fishery. SERI Studies No. 3. Sustainable Europe Research Institute, Vienna.

40. Crop Production. National Agricultural Statistical Services. September 7, 2007. United Stated Department of Agriculture. September 8, 2007. <http://www.usda.gov/ nass/PUBS/TODAYRPT/crop0907.txt>. (1/29/08).

41. Crop Harvest. Biological System Engineering: Crop Systems. Washington State University. September 19, 2007. 〈http://www.bsyse.wsu.edu/cropsyst/manual/parameters/crop/harvest.htm> $(1 / 29 / 08)$.

42. Forest Service. The Forest Inventory and Analysis RPA Assessment Tables. U.S. Forest Service. U.S. Department of Agriculture: Washington, DC. 2007.

43. IEA. International Energy Administration. International Energy Annual. USDOE: Washington, DC, 2006.

44. IFIA. International Fertilizer Industry Association. Statistics. 2008. http://www.fertilizer.org/ifa/statistics/IFADATA/summary.asp (6/27/08).

45. USDA. 2007. Major Land Uses. Economic Research Services. June 9, 2006. United States Department of Agriculture. September 9, 2007. http://www.ers.usda.gov/data/majorlanduses/. $(1 / 29 / 08)$.

46. Youngquist, W. GeoDestinies. The inevitable Control of Earth Resources over Nations and Individuals. National Book Company: Portland, Oregon, 1997.

47. USCB. Statistical Abstract of the United States, 2004-2005. U.S. Census Bureau, U.S. Government Printing Office: Washington, DC.

48. Pimentel, D.; Pleasant, A.; Barron, J.; Gaudioso, J.; Pollock, N.; Chae, E.; Kim, Y.; Lassiter, A.; Schiavoni, C.; Jackson, A.; Lee, M.; Eaton, A. U.S. Energy Conservation and Efficiency: Benefits and Costs. Environment, Development and Sustainability 2004, 6, 279-305.

49. Ferguson, A.R.B. Biomass and Energy. Manchester (United Kingdom). Optimum Population Trust 2001, 4 (1), 14-18.

50. Ferguson, A.R.B. Implications of the USDA 2002 Update on Ethanol From Corn. Manchester (United Kingdom). Optimum Population Trust 2003, 3 (1), 11-15.

51. Hendrickson, O.Q.; Gulland, J.F. Residential Wood Heating: Forest, the Atmosphere and Public Consciousness. Air and Waste Management Association Conference: The Emission Inventory: Living in a Global Environment. New Orleans, Louisiana, 1993.

52. EIA. Energy Information Administration. Annual Energy Review. U.S. Department of Energy: Washington, DC. 2007. http://www.eia.doe.gov/emeu/aer/pdf/aer.pdf (6/4/08).

53. Schill, S.R. Harnessing the Power of Biomass. Biomass Magazine. August, 2007. http://www.biomassmagazine.com/article-print.jasp?article_id=1229. (2/7/08).

54. Kitani, O. Biomass Resources. In CIGAR Handbook of Agricultural Engineering; Kitani, O.; Jungbluth, T.; Pearth, R.M.; Ramdani, A., Eds.; American Society of Agricultural Engineering: St. Joseph, MI, 1999, 6-11.

55. Pimentel, D. (Ed.) Biofuels, Solar and Wind as Renewable Energy Systems: Benefits and Risks; Springer: Dordrecht, The Netherlands, 2008, pp.504. 
56. Pimentel, D. Ecological Footprint, World population, and the Environment. 2007. http://www.brass.cf.ac.uk/uploads/fullpapers/Pimentel.pdf. (1/22/08).

57. Burning Issues. What Are the Medical Effects of Exposure to Smoke Particles? 2006. http://burningissues.org/health-effects.html. (12/07/07).

58. Smith, K.R. Health impacts of household fuelwood use in developing countries. 2006. http://ehs.sph.berkeley.edu/krsmith/publications/2006\%20pubs/Uasylva.pdf. (1/29/08).

59. EPA. Wood smoke. U.S. Environmental Protection Agency. 2002 http://www.webcom.com/bi/brochure.pdf+wood+smoke+pollution-hl=ene=UTF-8. (10/20/02).

60. USCB. U.S. Census Bureau. Gas Most Popular Home Heating Fuel, Census Bureau Shows. U.S. Census Bureau News. U.S. Department of Commerce, Washington, DC. Tuesday, November 16, 2004.

61. Health Effects of Wood Smoke. Department of Ecology. Air Quality Program. Washington State Energy Office. Olympia, Washington, 1997.

http://www.michigan.gov/documents/Health_Effects_of_Woodsmoke_WA_2004_142269_7.pdf (6/30/08).

62. Parikka, M. Global Biomass Fuel Reserve. Biomass Bioenergy 2004, 27, 613-620.

63. USCB. U.S. Census Bureau. Home Heating Fuels. 1990.

http://www.census.gov/apsd/cqc/cqc.27.pdf. (12/07/07).

64. EIA. Energy Information Administration “2001”. Residential Energy Consumption Survey.

Housing Characteristic Tables. 2002.

http://www.eia.doe.gov/emeu/recs/recs2001/detail_tables.html (2/15/08).

65. Forest Degradation Data. Forest Degradation Data. 2007.

http://home.alltel.net/bsundquist1/df0.html (1/21/08).

66. FAOSTAT. Food and Agricultural Organization. 2005. United Nations: Rome.

67. Arnold, J.E.M.; Jongma, J. Fuelwood and Charcoal in Developing Countries: An Economic Survey. 2007. http://www/faplo.org/docrep/12015e01.htm. (1/29/08).

68. Demirba, A. Biomass Resource Facilities and Biomass Conversion Processing for Fuels and Chemicals. Energy Convers Mgmt. 2001, 42, 1357-1378.

69. Fujino, J., Yamaji, K.; Yamamoto, H. Biomass-balance table for evaluating bioenergy resources. Applied Energy 1999, 62 (3), 75-89.

70. Howard, J.L. U.S. Timber Production, Trade, Consumption, and Price Statistics 1965 to 2002. Research Paper FPL-RP-615. Madison, Wisconsin: U.S. Department of Agriculture, U.S. Forest Service, Forest Products, Laboratory. 2003, 90 pages.

71. Birdsey, R.A. Carbon Storage and Accumulation in the United States Forest Ecosystems. USDA Forest Service: Washington, DC, 1992.

72. Repetto, R. Accounting for Environmental Assets. Scientific American 1992, 263, 94-100.

73. Trainer, F.E. Can Renewable Energy Sources Sustain Affluent Society? Energy Policy 1995, 23, 1009-1026.

74. Farrell, A.E.; Plevin, R.J.; Turner, B.T.; Jones, A.D.; O’Hare, M.O.; Kammen, D.M.Ethanol Can Contribute to Energy and Environmental Goals. Science 2006, 311, 506-508.

75. Shapouri, H.; Gallagher, P. USDA's 2002 Ethanol Cost-of-Product Survey: Agricultural Economic Report Number 841. U.S. Department of Agriculture, Washington, DC, 2005. 
76. NASS. National Agricultural Statistics Service. 2003. http://usda.mannlib.cornell.edu (11/05/04).

77. Patzek, T.W. Thermodynamics of the Corn-Ethanol Biofuel Cycle. Critical Review in Plant Sciences 2004, 23 (6), 519-567. http://petroleum.berkeley.edu/papers/patzek/CRPS416-PatzekWeb.pdf

78. Brees, M. Corn Silage Budgets for Northern, Central and Southwest Missouri. 2004. http://www.agebb.missouri.edu/mgt/budget/fbm-0201.pdf (9/1/04).

79. USDA. 1997. 1997 Census of Agriculture. U.S. Department of Agriculture. http://www.ncfap.org. (8/28/2002).

80. USDA.1997. Farm and Ranch Irrigation Survey (1998). 1997 Census of Agriculture. Volume 3, Special Studies, Part 1. 280 p.

81. Batty, J.C.; Keller, J. Energy Requirements for Irrigation. In Handbook Of Energy Utilization in Agriculture; Pimentel, D., Ed.; CRC Press: Boca Raton, FL, 1980; pp. 35-44.

82. Larsen, K.; Thompson, D.; Harn, A. Limited and Full Irrigation Comparison for Corn and Grain Sorghum.

2002.

http://www.colostate.edu/Depts/SoilCrop/extension/Newsletters/2003/Drought/sorghum.html (9/2/2002).

83. Larson, W.E.; Cardwell, V.B. History of U.S. Corn Production. University of Minnesota: Minneapolis, 1999.

84. USDA. Agricultural Statistics. U.S. Department of Agriculture. U.S. Government Printing Office: Washington, DC, 2002.

85. USDA. Corn-State. Costs of Production. U.S. Department of Agriculture, Economic Research Service, Economics and Statistics System, Washington, DC. Stock \#94018, 1991.

86. Patzek, T. The Real Corn-Ethanol Transportation System. 2006. http://petroleum.berkeley.edu/patzek/BiofuelQA/Materials/TrueCostofEtOH.pdf

87. Pimentel, D. Ethanol Fuels: Energy Balance, Economics, and Environmental Impacts are Negative. Natural Resources Research 2003, 12 (2), 127-134.

88. Blais, J.F.; Mamouny, K.; Nlombi, K.; Sasseville, J.L.; Letourneau, M. Les Mesures Deficacite Energetique dans le Secteur de Leau. J.L. In Les Mesures deficacite Energetique pour Lepuration des eaux Usees Municipales; Sassville, J.L.; Balis, J.F., Eds.; Scientific Report 405, Vol. 3., 1995, INRS-Eau: Quebec.

89. Illinois Corn. Ethanol's Energy Balance. 2004. http://www.ilcorn.org/Ethanol/Ethan_Studies/Ethan_Energy_Bal/ethan_energy_bal.html (8/10/04).

90. Kuby, W.R.; Markoja, R.; Nackford, S. Testing and Evaluation of On-Farm Alcohol Production Facilities. Acures Corporation. Industrial Environmental Research Laboratory. Office of Research and Development. U.S. Environmental Protection Agency: Cincinnati, OH. 1984; 100 p.

91. Newton, PW. Human Settlements Theme Report. Australian State of the Environment Report, 2001. http://www.environment.gov.au/soe/2001/publications/themereports/settlements/index.html (10/6/05). 
92. DOE. 2002. Review of Transport Issues and Comparison of Infrastructure Costs for a Renewable Fuels Standard. U.S. Department of Energy: Washington, D.C. 2002. http://tonto.eia.doe.gov/FTPROOT/service/question3.pdf (10/8/2002).

93. Koplow, D. Biofuels - At What Cost? Government Support for Ethanol and Biodiesel in the United States. The Global Studies Initiative (GSI) of the International Institute for Sustainable development (IISD). 2006. http://www.globalsubsidies.org/IMG/pdf/biofuels_subsidies_us.pdf $(2 / 16 / 07)$.

94. NAS. Frontiers in Agricultural Research: Food, Health, Environment, and Communities; National Academy of Sciences: Washington, DC, 2003. Also online: http://dels. http://books.nap.edu/openbook.php?isbn=0309084946 (7/14/08).

95. McLaughlin, S.B.; Walsh, M.E. Evaluating Environmental Consequences of Producing Herbaceous Crops for Bioenergy. Biomass and Bioenergy 1998, 14 (4), 317-324.

96. USDA. Statistics of Oilseeds, Fats, and Oils. USDA-NASS Agricultural Statistics, 2005. Chapter III. http://www.usda.gov/nass/pubs/agr05/acro05.htm. (10/20/2007).

97. Pimentel, D.; T. Patzek. Ethanol Production Using Corn, Switchgrass and Wood; Biodiesel Production Using Soybean. In Biofuels, Solar and Wind as Renewable Energy Systems: Benefits and Risks; Pimentel, D., Ed.; Springer: Dordrecht,

The Netherlands, 2008, Chapter 15, 375-396.

98. Searchinger, T.; Heimlich, R.; Houghton, R.A.; Dong, F.; Elobeid, A.; Fabiosa, J.; Tokgoz, S.; Hayes, D.; You, T. Use of U.S. Croplands for Biofuels Increases Greenhouse Gases Through Emissions From Land-use Change. Science 2008, 319, 1238-1240.

99. Socolow, R.; Hotinski, R.; Greenblatt, J.B.; Pacala, S. Solving the Climate Problem. Environment 2004, 46 (10), 8-19.

100. Hodge, C. Ethanol Use in US Gasoline Should be Banned, Not Expanded. Oil and Gas Journal September 9, 2002, 20-30.

101. Hodge, C. More evidence mounts for banning, not expanding, use of ethanol in gasoline. Oil and Gas Journal October 6, 2003, 20-25.

102. Jacobson, M.Z. Effects of Ethanol (E85) versus Gasoline Vehicles on Cancer and Mortality in the United States. Environmental Science and Technology 2007, 41(11), 4150-4157.

103. Davis, J.M.; Thomas, V.M. Systematic Approach to Evaluating Trade-offs Among Fuel Options: The lessons of MTBE. Annals of the New York Academy of Sciences. 2006, 498-515.

104. Tilman, D.; Hill, J.; Lehman, C. Carbon-negative Biofuels from Low-input High-diversity Grassland Biomass. Science 2006, 314, 1598-1600.

105. Rasnake, M. Tillage and Crop Residue Management. 1999. www.ca.uky.edu/agc/pubs/agr/agr99/agr99.htm (1/31/08).

106. Fryrear, D.W.; Bilbro, J.D. Wind Erosion Control With Residues and Related Practices. In Managing agricultural residues. P.W. Unger, Ed., Lewis Publ.: Boca Raton, FL, 1994, 7-17.

107. Lal, R. World Crop Residues Production and Implications of its Use as a Biofuel. Environment International 2005, 31 (4), 575-584.

108. Kim, S.; Dale, B.E. Life Cycle Assessment of Various Cropping Systems Utilized for Producing Biofuels: Bioethanol and Biodiesel. Biomass Engineering 2005, 29, 426-439. 
109. Troeh, F.R.; Hobbs, A.H.; Donahue. R.L. Soil and Water Conservation. Prentice Hall: New Jersey, 2004.

110. Lal, R. Soil Carbon Sequestration Impacts on Global Climate Change and Food Security. Science 2004, 34, 1623-1627.

111. Brummer, E.C.; Burras, C.L.; Duffy, M.D.; Moore, K.J. Switchgrass Production in Iowa: Economic Analysis, Soil Suitability, and Varietal Performance. Iowa State University: Ames, Iowa, 2000.

112. Samson, R. Switchgrass: A Living Solar Battery for the Prairies. Ecological Agriculture Projects, Mcgill University (Macdonald Campus, Ste-Anne-de-Bellevue, QC, H9X 3V9 Canada. Copyright@1991 REAP Canada.

113. Henning, J.C. Big Bluestem, Indiangrass and Switchgrass. Department of Agronomy, Campus Extension, University of Missouri, Columbia, MO. 1993.

114. Samson, R.; Duxbury, P.; Drisdale, M.; Lapointe, C. Assessment of Pelletized Biofuels. PERD Program, Natural Resources Canada, Contract 23348-8-3145/001/SQ, 2000.

115. Wood Tub Grinders. 2004. Wood Tub Grinders. http://p2library.nfesc.navy.mil/P2_Opportunity_Handbook/7_III_13.html (8/3/04).

116. Arkenol. Our Technology: Concentrated Acid Hydrolysis. 2004. www.arkenol.com/Arkenol\%20Inc/tech01.html (8/2/04).

117. Crisp, A. Wood residue as an energy source for the forest products industry. Australian National University. 1999. http://sres.anu.edu.au/associated/fpt/nwfp/woodres/woodres.html (7/10/06).

118. Brown, L.R. World's Rangelands Deteriorating Under Mounting Pressure. Earth Policy Institute. 2002. http://www.earthpolicy.org/Updates/Updates6.htm. (1/24/08).

119. Hos, J.J.; Groenveld, M.J. Biomass Gasification. In Biomass; Hall D.O.; Overend, R.P., Eds. John Wiley \& Sons: Chichester, UK, 1987, 237-255.

120. Jenkins, B.M. Pyrolysis Gas. In CIGAR Handbook of Agricultural Engineering; Kitani, O.; Jungbluth, T.; Pearth, R.M.; Ramdani, A., Eds.; American Society of Agricultural Engineering: St. Joseph, MI, 1999, 222-248.

121. Ellington, R.T.; Meo, M.; El-Sayed, D.A. The Net Greenhouse Warming Forcing of Methanol Produced from Biomass. Biomass and Bioenergy 1993, 4 (6), 405-418.

122. Osburn, L.; Osburn, J. Biomass Resources for Energy and Industry. 2001. http://www.ratical.org/renewables/biomass.html (10/20/02).

123. Hekkert, M.P.; van Giessel, J.F.; Ros, M.; Wietschel, M.; Meeus, M.T.H. The Evolution of Hydrogen Research: Is Germany Heading for an Early Lock-in? Journal of Hydrogen Energy 2005, 30, 1045-1052.

124. Ozaktas, T. Compression Ignition Engine Fuel Properties of a Used Sunflower Oildiesel Fuel Blend. Energy Sources 2000, 22 (4), 377-382.

125. Ali, M.B.; McBride, W.D. Soybeans: State Level Production Costs, Characteristics, and Input Use, 1990. Economic Research Service. Stock no. ERS SB873. 1990; 48pp.

126. College of Agricultural, Consumer and Environmental Sciences. Machinery Cost Estimates: Summary of Operations. University of Illinois at Urbana-Champaign. 1997. www.aces.uiuc.edu/ vo-ag/custom.htm (11/8/01). 
127. Economic Research Statistics. Soybeans: Fertilizer Use by State. Agricultural Chemical Usage: 1996 Field Crops $\quad$ Summary. 1997. http://usda.mannlib.cornell.edu/datasets/inputs/9X171/97171/agch0997.txt (11/11/01).

128. Hinman, H.; Pelter, G.; Kulp, E.; Sorensen, E.; Ford, W. Enterprise Budgets for Fall Potatoes, Winter Wheat, Dry Beans and Seed Peas under Rill Irrigation. Farm Business Management Reports, Columbia, Washington State University, Pullman, WA. 1992.

129. Pimentel, D.; Doughty, R.; Carothers, C.; Lamberson, S.; Bora, N.; Lee, K. Energy Inputs in Crop Production: Comparison of Developed and Developing Countries. In Food Security \& Environmental Quality in the Developing World; Lal, R.; Hansen, D.; Uphoff, N.; Slack, S., Eds.; CRC Press: Boca Raton, FL, 2002, 129-151.

130. Mississippi State University Extension Service. Agronomy Notes. 1999. http://msucares.com/newsletters/agronomy/1999/199910.html (7/10/06).

131. USDA. Agricultural Statistics, 2004. (CD-ROM) U.S. Department of Agriculture/ National Agriculture Statistics Service: Washington, DC. A1.47/2:2004.

132. Singh, R.P. Energy Accounting of Food Processing. In Energy in Food Processing; Singh, R.P., Ed.; Elsevier: Amsterdam, 1986, 19-68.

133. Duffy, M. Does planting GMO seed boost farmer's profits? Iowa State University, Leopold Center for Sustainable Agriculture, Leopold Letter, 1999, Volume 11, No. 3.

134. Artuzi, J.P.; Contiero, R.L. Herbicides Applied in Soybean and the Productivity of Corn in Succession. Pesquisa Agronpecuaria Brasilera 2006, 41 (7), 1119-1123.

135. USDA. Nutritive Value of American Foods. Agriculture Handbook No. 456. Agricultural Research Service. U.S. Department of Agriculture: Washington, DC, 1975.

136. Fyksen, J. Soybean Issues Tackled: 2007 Season, Varieties for Biofuel, Foliar Fungicides. 2008. http://agriview.com/articles/2008/01/24/crop_news/crops04.txt. (2/15/08).

137. Tickell J. Biodiesel America: How to Achieve Energy Security, Free America from Middle-east Oil Dependence, and Make Money Growing Fuel; Murphy, M.; Graziano, C., Eds.; Yorkshire Press, 2006, pp 121-140.

138. EBB. European Biodiesel Board. 2007. http://www/greencarcongress.com/2007/07europeanbiodie.html. (1/29/08).

139. Frondel M.; Peters J. Biodiesel: A New Oildorado? Energy Policy 2007, 35, 1675-1684.

140. Chamsing, A.; Salokhe, V.M.; Singh, G. Energy Consumption Analysis for Selected Crops in Different Regions of Thailand. (2004) Agricultural Engineering International: the CIGAR Ejournal. Manuscript EE 06 013, Vol. VIII, November. 2006.

141. USDA. 2007. The Price of Urea, the Primary Solid Nitrogen Fertilizer Used in the U.S., Rose from $\$ 200 \quad$ to $\$ 453 \quad$ Per http://www/ers.usda.gov/AmberWaves/November07/Findings/TightSupply.htm. (3/15/08).

142. Smathers, R.L. Winter Rapeseed after Summer Fallow. 2005 Northern Idaho Crop Costs and Returns Estimate. College of Agriculture and Life Sciences. University of Idaho. EBB1-WR-05.

143. Pimentel, D.; Pimentel, M. Food, Energy and Society. Colorado University Press, Boulder, CO, 1996.

144. Molenhuis, J. Business Analysis and Cost of Production Program. Ontario Ministry of Agriculture, Food and Rural Affairs. 2004. 
http://www.omafra.gov.on.ca/english/busdev/bear2000/Budgets/Crops/Oilseeds/wcanolahybrid_ static.htm (7/10/06).

145. Thoenes, P. Biofuels and Commodity Markets - Palm Oil Focus. FAO Commodities and Trade Division. Food And Agriculture Organization of the United Nations: Rome, 2007.

146. USDA. 2008. Foreign Agricultural Service. Oilseeds: World Markets and Trade Monthly

Circular. Major Vegetable Oils: World Supply and Distribution (Commodity View). February 8, 2008. U.S.Department of Agriculture. Washington, DC.

http://www.fas.usda.gov/oilseeds/circular/2008/February/Oilseeds0208.pdf (3/15/08).

147. MPOA. Malaysian Palm Oil Association and Sustainable Palm Oil: RSPO Public Forum on Sustainable Palm Oil; 6 January 2005; Mont Kiara Business Centre, Kuala Lumpur.

148. Carter, C.; Finley, W.; Fry, J.; Jackson, D.; Willis, L. Palm Oil Markets and Future Supply. European Journal of Lipid Science and Technology 2007, 109 (4), 307-314.

149. Pleanjai, S.; Gheewala, S.H.; Garivait, S. Environmental Evaluation of Biodiesel Production from Palm Oil in a Life Cycle Perspective. Presented at the Joint International Conference on "Sustainable Energy and Environment" in Hua Hin, Thailand, 1-3 December, 2004. 19 pages.

150. Donald, P.F. Biodiversity Impacts of Some Agricultural Commodity Production Systems. Conservation Biology 2004, 18 (1), 17-38.

151. World Agroforestry Centre. 2007.

http://www/worldagroforestrycentre.org/sites?TreeDB/aft/speciesPrinterFriendly. asp?ID=1013 $(11 / 4 / 07)$.

152. Haverkort, A.; Bindraban, P.; Bos, H. Food, Fuel or Forest? Proceedings of the seminary held at Wageningen, the Netherlands March 2, 2007. 66 pages.

153. Pacific Island Ecosystems. Jatropha curcas: Risk Assessment Results. 2007. http://www.hear.org/pier/wra/pacific/jatropha_curcas_htmlwra.htm. (11/4/07).

154. Dimitrov, K. GreenFuel Technologies: A Case Study for Industrial Photosythetic Energy Capture. Brisbane, Australia. 2007. http://moritz.botany.ut.ee/ oilli/b/Dimitrov.pdf. (3/11/08).

155. Briggs, M. Widescale Biodiesel Production from Algae. 2004. http://unh.edu/p2/biodielsel/article_algae.html. (1/7/08).

156. Vincent Inc. 2007. Valcent Products: Intial Data From the Vertigro Field Test Bed Plant Reports Average Production of 276 Tons of Algae Bio Mass on a Per Acre/per Year Basis. http://money.cnn.com/news.newsfeeds/articles/marketwire/0339181.htm. (1/7/08).

157. Green Car. Green Car Congress. 2006. http://www.greencarcongress.com/2006/07/malaysia_and_in.html. (1/7/08).

158. Goldman, J.C.; Ryther, J.H. Mass Production of Algae: Engineering Aspects. In Biological Solar Energy Conversion; Mitsui A. et al. Eds.; Academic Press: New York, 1977, 367-378.

159. Biopact. 2007. An In-Depth Look at Biofuels from Algae. http://biopact.com/2007/01/in-depthlook-at-biofuels-from-algae-html. (1/7/08).

160. CIIFAD. 2007. More Rice with Less Water. Cornell International Institute for Food, Agriculture and Development. http://ciifad.cornell.edu/SRI/estrmats/philmanual.pdf. (1/7/08).

161. Peak Soil. Peak Soil: Why biofuels are not sustainable and a Threat to America's National Security. 2008. http://www.ea2020.org/drupal/node/39. (1/31/08). 
162. Leiting, K.B. Agronomy - Corn and Soybeans Crop Residue Management. Natural Resource Conservation Service. Albuerque, New Mexico. 2007.

http://www/nm.nrcs.usda.gov/technical/tech-notes/agro/ag67.pdf. (10/9/07).

163. Khan, S.A.; Mulvaney, R.L.; Ellsworth, T.R.; Boast, C.W. The Myth of Nitrogen Fertilization for Soil Carbon Sequestration. Journal of Environmental Quality 2007, 36, 1821-1832.

164. Perlack, R.D.; Wright, L.L.; Turhollow, A.F.; Graham, R.L.; Stokes, B.J.; and Erbach, D.C. 2005. Biomass as Feedstocks for a Bioenergy and Bioproducts Industry: The Technical Feasibility of A Billion-Ton Annual Supply. (Report No. ORNL/TM-2005/66). Oak Ridge National Laboratory.

165. Lal, R.; Pimentel, D. Biofuels from Crop Residues. Soil and Tillage Research 2007, 93 (2), 237 238.

166. Prove, B.G.; Truong, P.N.; Evans, D.S. Strategies for Controlling Caneland Erosion in the Wet Tropical Coast of Queensland. Proceedings. Australian Society Sugar Cane Technology, 1986 Conference, pp.77-84.

167. Wortmann, C.S.; Jasa, P.J. 2003. Choosing the Right Tillage System for Row Crop Production. Institute of Agriculture and Natural Resources at the University of Nebraska: Lincoln, Nebraska.

168. Pimentel, D.; Hepperly, P.; Hanson, J.; Douds, D.; Seidel, R. Environmental, Energetic, and Economic Comparisons of Organic and Conventional Farming Systems. Bioscience 2005, 55 (7), 573-582.

169. Liebman, M. New Cropping Systems for Cellulosic Feedstock Production and Environmental Stewardship. 2008. http://129.186.41.143/20th/home.files/liebman.pdf. (1/31/08).

170. Mongabay. Forest Erosion. 2004. http://www.mongabay.co/0903.htm. (12/07/07).

171. Thornton, F. C.; Green, T. H.; Joslin, J. D.; Houston, A.; Bock, B. R., Schoenholtz, S.; Tyler, D. D.; Pettry, D. Environmental Impacts of Converting Cropland to Short-rotation Woody Crop Production: First Year Results. Proceedings of Bioenergy 1996 - The Seventh National Bioenergy Conference. September 15-20, 1996, Nashville, TN, p. 210-216.

172. IEA. International Energy Administration. International Energy Annual. USDOE: Washington, DC, 2001.

173. Naeher, L.P.; Brauer, M.; Lipsett, M.; Zelikoff, J.T.; Simpson, C.D.; Hoenig, J.Q.; Smith, K.R. Woodsmoke Health Effects: A Review. Inhalation Toxicology 2007, 19, 67-106.

174. Crutzen, P.J.; Mosier, A.R.; Smith, K.A.; Winiwerter, W. $\mathrm{N}_{2} \mathrm{O}$ Release from Agro-biofuel Production Negates Global Warming Reduction by Replacing Fossil fuels: Discussion. Atmospheric Chemical Physics 2007, 7, 11191-11205.

175. Brown, L.R. 2008. Why ethanol production will drive world food prices even higher in Earth Policy Institute. http://www.earthpolicy.org/Updates/2008/Update69.htm. (1/24/08).

176. Diouf, J. Biofuels a Disaster for World Food. In EU Coherence: EU Coherence Policy for Development. 2007. http://eucoherence.org/renderer.do/clearState/false/menuld/227351/return. (10/31/07).

177. United Nations Radio. Climate Change and Bio-Fuel Threaten Food Security, FAO Chief, November 26, 2007, www.un.org/radio/news/html/16436.html (1/22/2008). 
178. Southwestern University. Biology Research Finds Rising $\mathrm{CO}_{2}$ Levels Could Decrease the Nutritional Value of Major Food Crops. 2008. http://www.blackwellsynergy.com/doi/full10.1111/j.1365-2486.2007.01511.x. (2/15/08).

(C) 2008 by the authors; licensee Molecular Diversity Preservation International, Basel, Switzerland. This article is an open-access article distributed under the terms and conditions of the Creative Commons Attribution license (http://creativecommons.org/licenses/by/3.0/). 